
10

\title{
Prevalence of heterotrophic methylmercury detoxifying bacteria across oceanic regions
}

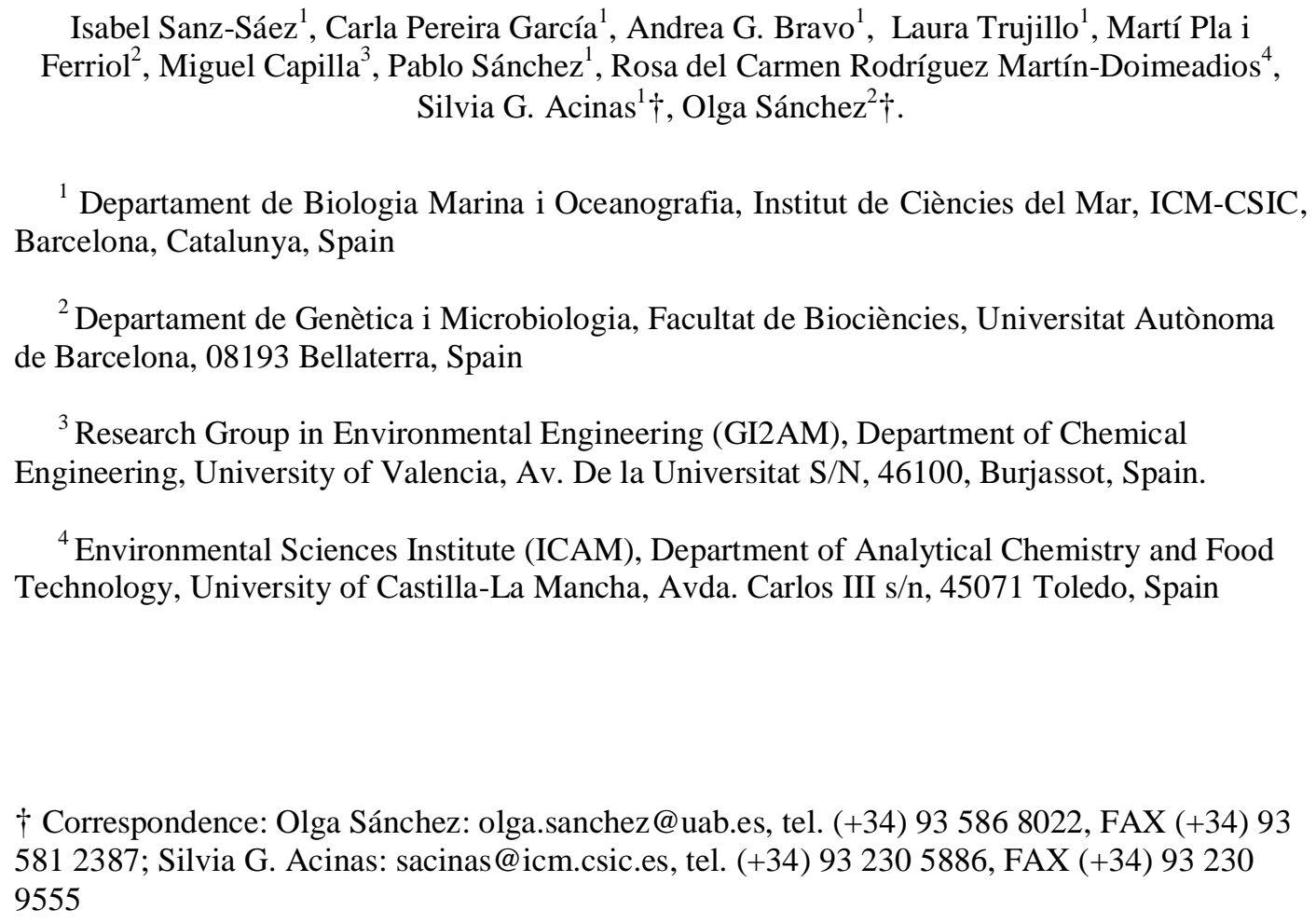

${ }^{1}$ Departament de Biologia Marina i Oceanografia, Institut de Ciències del Mar, ICM-CSIC, Barcelona, Catalunya, Spain

${ }^{2}$ Departament de Genètica i Microbiologia, Facultat de Biociències, Universitat Autònoma de Barcelona, 08193 Bellaterra, Spain

${ }^{3}$ Research Group in Environmental Engineering (GI2AM), Department of Chemical Engineering, University of Valencia, Av. De la Universitat S/N, 46100, Burjassot, Spain.

${ }^{4}$ Environmental Sciences Institute (ICAM), Department of Analytical Chemistry and Food Technology, University of Castilla-La Mancha, Avda. Carlos III s/n, 45071 Toledo, Spain

† Correspondence: Olga Sánchez: olga.sanchez@uab.es, tel. (+34) 93586 8022, FAX (+34) 93

581 2387; Silvia G. Acinas: sacinas@icm.csic.es, tel. (+34) 93230 5886, FAX (+34) 93230 9555 


\begin{abstract}
Microbial reduction of inorganic divalent mercury $\left(\mathrm{Hg}^{2+}\right)$ and methylmercury $(\mathrm{MeHg})$ demethylation is performed by the mer operon, specifically by merA and merB genes respectively, but little is known about the mercury tolerance capacity of marine microorganisms and its prevalence in the global ocean. Here, we explored the distribution of these genes in 290 marine heterotrophic bacteria (Alteromonas and Marinobacter spp.) isolated from different oceanographic regions and depths, and assessed their tolerance to diverse concentrations of $\mathrm{Hg}^{2+}$ and $\mathrm{MeHg}$. About $25 \%$ of the isolates presented merA and only $8.9 \%$ presented both merA $B$ genes, including the strain ISS312 that exhibited the highest tolerance capacity and a degradation efficiency of $98.2 \%$ in $24 \mathrm{~h}$. Fragment recruitment analyses of ISS312 genome against microbial metagenomes indicated an extensive distribution across the global bathypelagic ocean. Our findings highlighted that mercury resistance genes are widely distributed in a non-highly polluted environment such as the pelagic marine environment, and that degradation of the neurotoxic $\mathrm{MeHg}$ can be performed through the ocean water column by some heterotrophic bacteria at high efficiency with important implications in the biogeochemical cycle of mercury and potentially for the environment and human health.
\end{abstract}

Keywords: mercury, methylmercury, marine bacteria, mercury resistant bacteria, merA, mer $B$, minimum inhibitory concentration (MIC)

\title{
Teaser
}

Active mercury resistance genes detected in marine cultured bacteria are widely distributed in the ocean including the bathypelagic zone. 


\section{Introduction}

Mercury $(\mathrm{Hg})$ is one of the most toxic, widespread and worrisome contaminants $(1,2)$, which is emitted to the atmosphere by natural sources, such as volcanoes and rock weathering, but also by anthropogenic activities. Indeed, it has been estimated that anthropogenic $\mathrm{Hg}$ emissions have enriched present-day atmosphere by a factor of 2.6 relative to 1840 levels, and by a factor of 7.5 relative to natural levels (3). The rising $\mathrm{Hg}$ levels since the industrial era, estimated as an increase of $450 \%$ of $\mathrm{Hg}$ in the atmosphere (4), makes the study of its biogeochemical cycle a major concern to the scientific community and also to all the governments around the world. The Minamata convention, held in 2013 and entering into force in August 2017 (5), has been created to regulate the use of $\mathrm{Hg}$ and its releases to the environment in order to reduce its current levels.

Emitted elemental $\left(\mathrm{Hg}^{0}\right)$ and inorganic divalent $\mathrm{Hg}\left(\mathrm{Hg}^{2+}\right)$ can be deposited to land and oceans by wet and dry depositions $(6,7) . \mathrm{Hg}^{2+}$ in the ocean can be then volatilized back again to the atmosphere as $\mathrm{Hg}^{0}(8)$, or can be methylated (9-13) forming methylmercury (MeHg), which bioaccumulates and biomagnifies in aquatic food webs $(4,14,15)$. As a consequence, humans are exposed to this neurotoxicant mainly through fish and seafood consumption $(14,16,17)$. $\mathrm{MeHg}$ levels in the oceans vary with depth, and usually, measures are being reported low in open ocean surface waters, maximal in intermediate layers, especially in regions of low-oxygen and near or below the thermoclines (up to $1000 \mathrm{~m}$ depth), and low and relatively constant in deeper waters $\left(>1000 \mathrm{~m}\right.$ depth) $(14,18,19)$. While $\mathrm{Hg}^{2+}$ methylation has been reported to occur in oxic and sub-oxic layers of the water column $(9,18,20-22)$ mainly associated with the microbial remineralization of sinking particulate organic matter $(18,19,23)$, much less is known about $\mathrm{MeHg}$ demethylation and $\mathrm{Hg}^{2+}$ reduction processes in the ocean water column. Although $\mathrm{MeHg}$ demethylation and $\mathrm{Hg}^{2+}$ reduction processes can be photochemically mediated (24-26), light penetration in the ocean water column is limited to $200 \mathrm{~m}$ (27), thereby biological $\mathrm{MeHg}$ degradation and $\mathrm{Hg}$ reduction processes likely govern in the ocean water column.

Biological MeHg demethylation and $\mathrm{Hg}^{2+}$ reduction detoxification processes are mediated by the mer operon $(28,29)$. While the operon can be composed by different sets of genes $(28,29)$, the operon key genes are merA and merB. The first one codifies a mercuric reductase and is responsible for the transformation of $\mathrm{Hg}^{2+}$ to the less harmful and volatile $\mathrm{Hg}^{0}$ (28). The merB gene encodes an organomercurial lyase enzyme that confers resistance to the organic $\mathrm{MeHg}$ form. It is the responsible for its demethylation releasing $\mathrm{Hg}^{2+}$ that will be then reduced to $\mathrm{Hg}^{0}$ by merA gene (28). These machineries have been found in numerous microorganisms including 
aerobic and anaerobic species, although demethylation appears to be predominantly accomplished by aerobic organisms $(29,30)$. To date, very few studies have reported the presence of mer genes in oceanic waters, with the exception of some studies in the North Pacific and Arctic Oceans (31) and a recent analysis in the global bathypelagic ocean (Bravo \& Sanz et al. unpublished). Taking into account that different concentrations of $\mathrm{MeHg}$ can be found through the ocean water column $(21,32-34)$, it would be however plausible to find microorganisms with the $\mathrm{Hg}$ detoxification capacity. In this study we took advantage of the MARINHET (35) culture collection, that includes a total of 2003 marine bacterial strains from a wide variety of oceanographic regions and depths, to perform a functional screening of the merA and merB genes in 290 marine heterotrophic bacteria with the aim to detect marine bacteria codifying mer genes. Moreover, we assessed their tolerance to different concentrations of inorganic $\left(\mathrm{Hg}^{2+}\right)$ and organic monomethylmercury (MeHg).

Most of the studies focusing on the isolation of marine $\mathrm{Hg}$ resistant bacteria have targeted coastal seawaters $(36-38)$, sediments $(37,39)$, mangroves and estuaries $(40-42)$ hydrothermal vents (43), and specially highly contaminated sites $(44,45)$ and have overlooked the open ocean including the bathypelagic ocean. Identification of $\mathrm{Hg}$ resistant bacteria in contrasting aquatic ecosystems and the assessment of their tolerance to different concentrations of $\mathrm{MeHg}$ provides new opportunities to explore the ubiquity, prevalence of marine cultured bacteria with detoxification capacity in the open ocean (i.e. non-contaminated sites), and also, it appears to be an interesting starting point for bioremediation strategies.

\section{Results and Discussion}

\subsection{Presence of merA and merB genes among Alteromonas and Marinobacter strains}

$\mathrm{Hg}$ resistance genes have been found in multiple Gram-negative and Gram-positive bacteria, and isolates containing the mer operon have been retrieved from many environments (46-52), including different marine ecosystems $(36,43,53,54)$. However, most of the studies have found them in highly contaminated environments and their presence in pelagic open ocean environments have been largely overlooked. We used the MARINHET bacterial culture collection (35), which included strains from different depths, such as the surface, the deep chlorophyll maximum and the bathypelagic zone, as well as from diverse oceanographic regions, to explore the presence of the mer operon in non-contaminated sites. We detected a total of 20 different bacterial taxa in the IMG/JGI database that matched at the genera level with the taxonomic assignation of the MARINHET culture collection isolates, and therefore, with 
potential for carrying merA and merB genes (Supplementary Table S1). The comparative analyses between the 16S rRNA gene sequences of these 20 genera containing the targeted merA and merB genes and the partial 16S rRNA sequences of our isolates revealed a total of 352 strains that were, at least, $99 \%$ identical to one of the putative candidates genera. These comprised 7 genera (Alteromonas, Marinobacter, Idiomarina, Pseudomonas, Micrococcus, Zunongwangia and Bacillus) (Supplementary Table S2). From these, we selected a total of 244 strains affiliating to Alteromonas sp. and 46 strains to Marinobacter sp. (Supplementary

Table S3). These two genera were chosen for merA and merB functional screening for several reasons: (i) they are among the most common culturable heterotrophic bacteria living in open marine waters all around the world, as they have been isolated from a wide variety of marine environments (55-61), and in the case of Alteromonas it is one of the most ubiquitous cultured taxa in the ocean (35), (ii) it has been already described that species of those genera harbor in their genomes the mer operon $(59,62-65)$ and finally (iii) they were found highly abundant in our MARINHET culture collection.

The functional screening of the merA and merB genes from the 244 Alteromonas and 46 Marinobacter strains revealed that $13.5 \%$ (32 out of 244) and $89.1 \%$ (41 out of 46) of the strains presented only merA, respectively, while only $1.6 \%$ (4 out of 244), and $47.8 \%$ (22 out of 46) presented both merA and merB genes (merAB) (Table 1). These results showed that Marinobacter displayed a higher proportion of merAB genes than Alteromonas. In addition, our results showed that the merB gene was found in lower proportion than merA among both Alteromonas and Marinobacter strains, being these results consistent with the known fact that the mer operon does not always codify for the organomercurial lyase necessary for the detoxification of organic $\mathrm{Hg}$ compounds $(28,29)$. In addition, studies targeting the abundance of mer genes in the environment reported that merA is found to be widely distributed among marine bacteria $(29,31,66)$, while $\operatorname{merB}$ only has an ecological significance in determined systems where $\mathrm{MeHg}$ is present at high concentrations (67). Here, we demonstrate that both merA and merB might be present even in pristine environments such as the open ocean.

\subsection{Biogeographic distribution of isolated strains codifying mer genes}

The strains screened for mer $A B$ genes were isolated from different oceanic regions such as the North Western Mediterranean Sea (89), South (101) and North Atlantic (42), Indian (44), Arctic (7) and Southern (7) Oceans and included isolates from photic (160) and aphotic (130) layers (Table 2). We obtained positive strains (merA and/or merAB) from the different depths and oceanographic regions, except for the Arctic Ocean (Figure 1 and Supplementary Table S4). For Alteromonas sp., station (ST) 32 from the bathypelagic in the South Atlantic Ocean and 
ST151 from surface of the North Atlantic Ocean were the ones with a larger number of positive strains (Figure 1), while ST76 and ST67 from surface South Atlantic Ocean followed by ST8 of the bathypelagic North Western Mediterranean Sea were the ones which presented more positive Marinobacter strains (Figure 1). No significative differences were found between oceans (ANOVA, P-value > 0.05) but in general, we found a higher proportion of positive strains coming from waters of the Southern Ocean $(71 \%$ despite the lower number of strains tested) and the South Atlantic Ocean (48\%), followed by those retrieved from the North Atlantic (17 \%) and North Western Mediterranean Sea (13\%). However, total $\mathrm{Hg}$ concentrations have been recorded to be higher in the Mediterranean and the North Atlantic Ocean compared to the South Atlantic and Southern Oceans, where concentrations were lower (34). Nevertheless, some studies have highlighted the important but also variable levels of $\mathrm{MeHg}$ found in Southern and other polar waters compared to open ocean $(32,68)$, and isolation of $\mathrm{Hg}$ resistance bacteria from those polar waters has been previously reported (52). It must be noticed that our results only represent a minor fraction of all potential isolates that may harbor $m e r A B$ genes, since our primers only targeted Alteromonas and Marinobacter genera, and only specific merA gene variants. Thus, correlation between levels of $\mathrm{Hg}$ and positive strains cannot be properly assessed.

Regarding the presence of the mer $A$ and mer $A B$ genes across the ocean layers, isolates came from both depths and $27 \%$ and $23 \%$ of the total surface and the deep-ocean isolates screened, respectively, gave positive results. Although, no significative differences were found between depths (ANOVA, P-value >0.05) our findings unveiled the pattern of vertical distribution of these mer $A B$ genes distributed along different water depths including bathypelagic waters.

\subsection{High variability of mercury tolerance within marine bacteria}

It is unknow whether mercury tolerance is a conservative trait within marine bacterial strains of the same genera. MIC experiments were addressed in a selection of the 74 isolates that presented merA and/or merAB genes. This selection was based on a clustering of the 16S rRNA gene of the isolates at $99 \%$ sequence similarity to define operational taxonomic units (OTUs). The clustering grouped the isolates into 8 OTUs, and representatives of different OTUs were randomly selected for MIC experiments (Supplementary Table S5). First, we tested the tolerance for inorganic mercury $\left(\mathrm{HgCl}_{2}\right)$ and 42 isolates (19 Alteromonas and 23 Marinobacter) displayed different levels of tolerance. MIC values ranged generally from 10 to $50 \mu \mathrm{M}$. Around $50 \%$ of the Alteromonas and Marinobacter strains tested presented a MIC of $20 \mu \mathrm{M}$ and one of the isolates stood out as it presented a tolerance to $\mathrm{HgCl}_{2}$ up to $70 \mu \mathrm{M}$ (Supplementary Table S6). Different tolerances were found within the same phylogenetic cluster based on 16S rRNA 
genes (Figure 2) but also within strains belonging to the same OTUs (99\% sequence similarity, Figure 2). For example, within the cluster of Alteromonas mediterranea some strains presented a MIC of $20 \mu \mathrm{M}$, while the isolate that presented the highest tolerance (70 $\mu \mathrm{M}$, ISS312) also belonged to the same Alteromonas species (Figure 2). The same occurred among Marinobacter isolates, where members of the Marinobacter hydrocarbonoclasticus cluster presented MIC values ranging from 10 to $50 \mu \mathrm{M}$ (Supplementary Table S6 and Figure 2).

The amino acids merA phylogeny, which theoretically could include the different gene sequences variants covered by the primers designed, unveiled that all the Alteromonas merA sequences grouped into two sister clades with the reference Alteromonas mediterranea merA sequence (Figure 3) and MIC variability was more clearly observed here as sequences clustering together presented MIC values ranging from $20 \mu \mathrm{M}$ to $70 \mu \mathrm{M}$. For Marinobacter, the merA genes grouped into three different clusters showing genetic heterogeneity among their merA genes copies (Figure 3). Those sequences of the Marinobacter sp. Arc7-DN-1 cluster presented a MIC that varied between $20 \mu \mathrm{M}$ and $50 \mu \mathrm{M}$, while those of the merA sequences affiliating to Marinobacter salarius and Marinobacter hydrocarbonoclasticus ranged from 10 $\mu \mathrm{M}$ to $50 \mu \mathrm{M}$ (Figure 3).

On the other hand, in order to test the tolerance to $\mathrm{MeHg}$ amended in form of $\mathrm{CH}_{3} \mathrm{HgCl}$, three strains affiliating to Alteromonas mediterranea that codified for the merB gene and presented a MIC for $\mathrm{HgCl}_{2}$ above $20 \mu \mathrm{M}$ were selected. Remarkably, these strains presented a high tolerance to $\mathrm{MeHg}$, growing at concentrations up to $10 \mu \mathrm{M}$ (Figure 3) and the merAB aminoacids sequences clustered all together, as expected, with Alteromonas mediterranea reference sequence (Supplementary Figure S1). Among the Marinobacter sp. harboring merAB genes, the two strains having a MIC for $\mathrm{HgCl}_{2}$ above $20 \mu \mathrm{M}$ did not show a substantial growth above $2.5 \mu \mathrm{M}$ of $\mathrm{MeHg}$ (Figure 2).

The MIC values heterogeneity within strains belonging to the same OTU or phylogenetic cluster, suggested that the level of $\mathrm{Hg}$ resistance was isolate specific, and that maybe we retrieved different ecotypes within a same species with different tolerances to $\mathrm{Hg}$. In addition, the operon mer can be either codified in the chromosome $(69)$ or in plasmids $(28,70)$, and usually, mer genes are components of transposons $(71)$, and integrons $(72,73)$. Thus, different copies of the mer genes including maybe different sequence variants $(29,74)$, could be found within a same strain providing to the strains different tolerances to mercury compounds. This specificity is further supported by the fact that no correlation was observed between the ability to reduce $\mathrm{Hg}$ and the taxonomic groups observed in the phylogenetic trees, although negative results should be interpreted with caution. Similar results were obtained in previous studies 
indicating the isolate-specific resistance to $\mathrm{Hg}(44,75)$. Despite these differences between strains, the tolerances found for inorganic $\mathrm{Hg}$ were similar to those found in other studies where Alteromonas $(40,65,69,76)$ and Marinobacter (43) genera were also isolated from different marine ecosystems such as hydrothermal vents, estuaries or contaminated sediments. However, to the best of our knowledge, this is the first study addressing the tolerance of Marinobacter spp. and Alteromonas mediterranea isolated from the ocean to MeHg. Hence, we found out that a strain affiliating to Alteromonas mediterranea (ISS312) presented a MIC to inorganic $\mathrm{Hg}$ higher than other strains already published, up to $70 \mu \mathrm{M}$, but we also determined that it was able to grow in the presence of $\mathrm{MeHg}$, presenting a $\mathrm{MIC}$ up to $10 \mu \mathrm{M}$. It is noteworthy that the tolerant strains to $\mathrm{HgCl}_{2}$ and/or to $\mathrm{MeHg}$ were resistant to much higher concentrations of $\mathrm{Hg}$ than those reported in different oceans, which usually range from $<0.1$ to $10 \mathrm{pM}(34,77)$.

\subsection{Description of the highly tolerant Alteromonas sp. strain ISS312}

Strain ISS312, isolated from South Atlantic bathypelagic waters at $4000 \mathrm{~m}$, affiliated to the species Alteromonas mediterranea. It displayed the highest tolerance to both $\mathrm{HgCl}_{2}(70 \mu \mathrm{M})$ and $\mathrm{MeHg}(10 \mu \mathrm{M})$ and it could be a good candidate for future bioremediation studies in highly contaminated areas with both organic and inorganic mercuric compounds. Consequently, the growth rates of this isolate at different concentrations of $\mathrm{MeHg}$ were assessed. Tested concentrations were selected based on MIC results and included: a control without $\mathrm{MeHg}(0$ $\mu \mathrm{M}), 1 \mu \mathrm{M}, 2.5 \mu \mathrm{M}$ and $5 \mu \mathrm{M} \mathrm{MeHg}$. Growth curves at $0 \mu \mathrm{M}$ and $1 \mu \mathrm{M}$ were very similar, as well as between $2.5 \mu \mathrm{M}$ and $5 \mu \mathrm{M}$ (Figure $4 \mathrm{~A}$ ). We observed that the major difference between growth curves was the length of the lag phase, where bacteria adapt themselves to the growth conditions. Cultures showed a longer lag phase in the highest concentration of $\mathrm{MeHg}$, around 13 h, compared to the control, which started to grow immediately after inoculation (Figure 4A). This phenomenon seems to be a common trait for $\mathrm{Hg}$ resistant strains in the presence of the toxic compound, as this behavior has been repeatedly observed in different species of Pseudomonas sp., Alcaligenes sp. or Bacillus sp. (37, 53, 78). Lag phase length declined as long as the concentration of $\mathrm{MeHg}$ decreased, being $6 \mathrm{~h}$ at $2.5 \mu \mathrm{M}$ and $2 \mathrm{~h}$ at $1 \mu \mathrm{M}$. However, once the cultures started to grow, their growth rates $\left(\mu_{\max }\right)$ were very similar independently of their initial $\mathrm{MeHg}$ concentrations, ranging from $0.10 \mathrm{~h}^{-1}$ in the control to $0.09 \mathrm{~h}^{-1}$ at $5 \mu \mathrm{M}$. Stationary phase was reached in all concentrations at $80 \mathrm{~h}$, even though at this time cultures at higher concentrations of $\mathrm{MeHg}$ seemed to be only entering to the plateau (Figure 4A). In addition, their carrying capacity $(\mathrm{k})$, i.e. the maximum population size of a species, was between 1.6 and 1.9 based in O.D. measures, revealing very similar values between tested concentrations, an observation also recurrently reported $(37,79)$. TEM observations of the ISS312 cultures 
growing at $0 \mu \mathrm{M}$ and $5 \mu \mathrm{M}$ of $\mathrm{MeHg}$ also showed similar morphology and ultrastructure of the cells (Figure 4A).

In addition, samples for the measurement of $\mathrm{MeHg}$ concentrations during the growth of the strain ISS312 in experiments at $5 \mu \mathrm{M}$ were taken at different incubation times. Samples were also collected for the $1 \mu \mathrm{M}$ growth curves, but as similar degradation kinetics were observed for both concentrations (Supplementary Table S7), we have only presented the results from the 5 $\mu \mathrm{M}$ growth curve where we were able to detect a great capacity to remove $\mathrm{Hg}$ by strain ISS312 (Figure 4B). Hence, in samples taken at $6 \mathrm{~h}$ and $12 \mathrm{~h}$, which corresponded to the lag phase of the growth curve, we observed that $\mathrm{MeHg}$ concentrations were reduced by $36 \%(2.6 \mu \mathrm{M})$ and $72 \%(1.1 \mu \mathrm{M})$, respectively (Figure 4B). Furthermore, at time $24 \mathrm{~h}$, when almost all $\mathrm{MeHg}$ was removed (with a concentration of only $0.07 \mu \mathrm{M}$, and a removal of $98.2 \%$ ) the microorganism began the exponential growth phase. After $48 \mathrm{~h}$, MeHg could not be detected (Figure 4B Supplementary Table S7). Based on the results obtained, it can be hypothesized that during the lag phase, in the presence of $\mathrm{MeHg}$, the mer operon machinery is being activated by the MerR protein involved in the regulation of the operon, and MerA and MerB proteins are subsequently transcribed to catalyze, first, the demethylation of $\mathrm{MeHg}$ to $\mathrm{Hg}^{2+}$ (MerB), and then its transformation to $\mathrm{Hg}^{0}$ (MerA), which is then volatilized. Once the levels of $\mathrm{Hg}$ compounds have dropped considerably, and are no longer toxic, cells can grow normally reaching standard growth rates and continue to remove $\mathrm{MeHg}$ until very low concentrations of inorganic $\mathrm{Hg}$ remained, evidencing the high detoxification capability of strain ISS312, comparable to other Hg resistant bacteria characterized for bioremediation strategies (80).

We assumed that most of the $\mathrm{MeHg}$ was degraded biotically by the mer operon encoded in ISS312, but a fraction could also be abiotically removed. In order to check which proportion of $\mathrm{MeHg}$ was either biotically or abiotically removed, we took additional samples at times $0 \mathrm{~h}$ and $72 \mathrm{~h}$ from the strain culture and from different control treatments (a killed control and medium alone) in the presence of $\mathrm{MeHg}$. As expected, in the culture we did not observe any remaining $\mathrm{MeHg}$ at $72 \mathrm{~h}$. However, we detected a certain level of abiotic degradation in the medium and killed controls (Supplementary Table S8). We found that $\mathrm{MeHg}$ concentration was reduced by $25 \%$ in the absence of bacteria, suggesting that three quarters could be removed biotically while the rest could be degraded by abiotic processes. Still, most part of the $\mathrm{MeHg}$ transformation to $\mathrm{Hg}^{2+}$ and then to volatile $\mathrm{Hg}^{0}$ is caused by ISS312 strain by the operation of merA and merB genes confirming the idea that biotic $\mathrm{MeHg}$ degradation would play a major role in the open ocean, and especially in the bathypelagic as this strain was originally isolated from those deep waters. 


\subsection{Global distribution of ISS312 merAB genes in the bathypelagic ocean}

The biogeographic and size fraction distribution of ISS312 genome was assessed in all available bathypelagic metagenomes of the Malaspina Expedition since isolate ISS312 was originally retrieved from bathypelagic waters of the South Atlantic Ocean. We found that this strain affiliating to Alteromonas mediterranea species was distributed across all the temperate bathypelagic waters, including the Atlantic, the Pacific and the Indian Oceans (Figure 5). Its abundances, according to the data from the fragment recruitment analyses (FRA), varied across ocean basins and we found significative differences between the Pacific and the Brazil basins $(\mathrm{P}$-value $=0.019)$, and between the Pacific and the Canary basins (P-value: 0.011), suggesting a higher abundance of this bacterium in the Atlantic Ocean. Despite finding these differences between oceans, we did not find significative differences between plankton size fractions, indicating that the isolate could be present in both the free-living $(0.2-0.8 \mu \mathrm{m})$ and particleattached $(0.8-20 \mu \mathrm{m})$ bacterial communities (Figure 6). This analysis confirmed, at least for Alteromonas mediterranea, the prevalence and wide distribution of this bacterial species carrying $\mathrm{Hg}$ resistance genes, which can actively degrade the toxic $\mathrm{MeHg}$, across the global bathypelagic ocean, and its occurrence in both plankton size fractions analyzed. In fact, Alteromonas genus has been described to be able to live associated to particulate organic matter $(65,81)$, which forms in surface layers and sinks into the deep ocean. Besides, merA and merB genes affiliating to Alteromonas have been already detected among the microbial communities associated to sinking particles (64). In addition, $\mathrm{MeHg}$ production, presenting its maximum concentrations in deeper waters $(200-1000 \mathrm{~m}$ depth) $(14,18,19)$ usually near the thermocline, is linked to microbial remineralization of particulate organic matter $(18-20,23,33)$. Thereby, this study has uncovered that heterotrophic isolated bacteria from genus Alteromonas containing mer genes are present in the open ocean from different oceanographic regions, depths and plankton size fractions. These taxa carried in their genomes the key genes for the detoxification of $\mathrm{Hg}$ toxic compounds. To the best of our knowledge the detection of mer genes from noncontaminated sites and in open ocean waters at a large scale has not been previously reported.

\subsection{Outlook}

In summary, this study, that nourishes from a large marine bacterial culture collection, offers the first description of the presence and distribution of merA and merB genes, as well as, the assessment of the tolerance capacity (activity) to mercury compounds, in Alteromonas and Marinobacter strains, at a broad scale covering different oceanographic regions and depths including the bathypelagic ocean. $\mathrm{Hg}$ resistant Alteromonas and Marinobacter strains were detected in samples from photic and deep ocean waters including the NW Mediterranean Sea, 
the North and South Atlantic, the Southern and the Indian Oceans. Our results highlighted that mercury resistance genes are widely distributed in the open ocean, and that degradation of the neurotoxic MeHg can be performed through the ocean water column by some specific taxa at high efficiency with important implications in the biogeochemical cycle of mercury and potentially for the environment and human health. Specifically, we have revealed that Alteromonas mediterranea strain ISS312 isolated from bathypelagic waters of the South Atlantic Ocean is widely distributed in the global bathypelagic ocean both in the free-living and the particle-attached bacterial communities. Given its high tolerance, the growth rates observed, its efficiency in the removal of $\mathrm{MeHg}$, and its global oceanic distribution, this isolate could be a promising candidate for future $\mathrm{Hg}$ marine bioremediation studies.

\section{Material and Methods}

\section{1 Selection of marine strains for merAB functional screening}

A total of 2003 marine strains were previously isolated from a wide variety of oceanographic regions and depths. Detailed sampling, isolation procedures and partial sequencing of the $16 \mathrm{~S}$ rRNA gene have been already described in Sanz-Sáez et al. (35). This heterotrophic marine bacterial culture collection, called MARINHET, was the basis for the functional screening of $\mathrm{Hg}$ resistant bacteria and the description of the distribution of mercury resistance genes of this study. First, we performed a preliminary search of marine genera codifying both merA and $m e r B$ in all available finished genomes in the Integrated Microbial Genomes (IMG) database at that time (March 2016) of the Joint Genome Institute (JGI) by: (i) searching the functional annotation of merA (as mercuric reductase or mercuric ion reductase) and merB (organomercurial lyase or alkylmercury lyase), and (ii) using the Kyoto Encyclopedia of Genes and Genomes (KEGG) orthologs (82) K00520 for merA and K00221 for merB. Secondly, we downloaded the 16S rRNA gene sequences of those genomes in order to BLASTn (83) them against the partial $16 \mathrm{~S}$ rRNA sequences of our isolates and to obtain a list of putative candidates carrying the merA and merB genes. From those, we focused on two genera, Alteromonas and Marinobacter, highly abundant taxa in our MARINHET cultured collection. A total 290 isolates from both Alteromonas (244) and Marinobacter (46) genera were finally selected for functional screening of the $\mathrm{Hg}$ resistance genes merA and $m e r B$. These strains originated from a variety of oceanographic regions and depths and covered both the photic and aphotic regions of the water column. Information about the origin of the samples where isolates were retrieved is summarized in Table 2.

\subsection{Primers design for merA and merB genes}


Sequences of the merA and merB genes were downloaded from IMG/JGI. First, we looked for "mercuric reductase" or "mercuric ion reductase" ( $m e r A)$ and "organomercurial lyase" or "alkylmercury lyase" (merB) genes in the published finished genomes of 22 Alteromonas and 6 Marinobacter (IMG database in 2016). Then, we downloaded the nucleotide sequences of 15 merA and 1 merB genes present in those Alteromonas genomes, as well as 9 merA and 1 merB genes from Marinobacter (Supplementary Table S9). Specific primers pairs were designed separately for: (i) merA of Alteromonas, (ii) merA of Marinobacter, (iii) merA + merB of Alteromonas, and (iv) merA + merB of Marinobacter. Both sets of merA primers were selected after alignments of the sequences in Clustal Omega (https://www.ebi.ac.uk/Tools/msa/clustalo/) in order to check for the most conserved areas of the gene. For Alteromonas, as different merA gene copies could be present within the same genome, the designed primers only covered the gene/s copies with the highest similarity between them and between the taxa, since evidence of horizontal gene transfer has been detected in mer genes, usually in plasmids, transposons or genomic islands (65) (Supplementary Table S9). On the other hand, as Marinobacter merA sequences differ greatly from species to species and most of the Marinobacter isolates present in our culture collection affiliated to Marinobacter hydrocarbonoclasticus or Marinobacter salarius, primers were designed to cover the merA sequence variants of these species (Supplementary Table S9). Otherwise, as merB genes were only found in Alteromonas mediterranea DE strain (CP003917) and Marinobacter aquaeolei VT8 strain (NC_008740) (also named Marinobacter hydrocarbonoclasticus VT8), merA + merB sets of primers were designed with the online tool Primer-BLAST of the National Center for Biotechnology Information (https://www.ncbi.nlm.nih.gov/tools/primer-blast/). The input sequence for the generation of these primers was a concatenate nucleotide sequence of the merA and merB genes that were co-localized one next to the other in the mer operon (Figure 6A). All the designed primers had to meet the following requirements: optimum polymerase chain reaction (PCR) product size of $1200 \mathrm{bp}$ for merA or $2100 \mathrm{bp}$ for merA + merB (referred hereafter as merAB), annealing temperature around $57^{\circ} \mathrm{C}$, primers length $20 \mathrm{bp}$, and $50 \% \mathrm{GC}$ content. In Figure 6B we summarize the sequences of the different sets of primers used in this study.

\subsection{DNA extraction and PCR conditions}

The primers previously designed were used for the screening of merA and merAB Hg resistance genes in the 290 selected strains. DNA of all the strains was extracted from $48 \mathrm{~h}$ liquid cultures grown in Zobell broth medium (i.e. $5 \mathrm{~g}$ peptone, $1 \mathrm{~g}$ yeast extract in $750 \mathrm{ml}$ of $30 \mathrm{kDa}$ filtered seawater and $250 \mathrm{ml}$ of Milli-Q water) using the DNeasy Blood \& Tissue kit (Qiagen) following the manufacturer's recommendations. Each PCR reaction with a final volume of $25 \mu 1$ 
contained: $2 \mu 1$ of template DNA, $0.5 \mu 1$ of each deoxynucleotide triphosphate at a concentration of $10 \mu \mathrm{M}, 0.75 \mu \mathrm{l}$ of $\mathrm{MgCl}_{2} 1.5 \mathrm{mM}, 0.5 \mu \mathrm{l}$ of each primer at a concentration of $10 \mu \mathrm{M}, 0.125 \mu \mathrm{l}$ of Taq DNA polymerase (Invitrogen), $2.5 \mu 1$ of PCR buffer supplied by the manufacturer (Invitrogen, Paisley, UK) and Milli-Q water up to the final volume. Reactions were carried out in a Biorad thermocycler using the following program: initial denaturation at $94{ }^{\circ} \mathrm{C}$ for $5 \mathrm{~min}$, followed by 30 cycles of $1 \mathrm{~min}$ at $94{ }^{\circ} \mathrm{C}, 1 \mathrm{~min}$ at $55^{\circ} \mathrm{C}$ and $2 \mathrm{~min}$ at $72{ }^{\circ} \mathrm{C}$, and a final extension step of $10 \mathrm{~min}$ at $72{ }^{\circ} \mathrm{C}$. The PCR products were verified and quantified by agarose gel electrophoresis with a standard low DNA mass ladder (Invitrogen). Purification and OneShot Sanger sequencing of merA and merAB gene products was performed by Genoscreen (Lille, France) with both forward and reverse primers. Geneious software v.11.0.5 (84) was used for manual cleaning and quality control of the sequences.

\subsection{Phylogenetic analyses of the 16S rRNA genes and merA or merAB gene of positive strains}

A phylogeny of the isolates screened by PCR for merA and merAB genes was inferred from their partial 16S rRNA sequences in order to detect a possible clustering between all the positive strains. The closest sequence to each isolate 16S rRNA gene in SILVA v.132 database was found and collected using BLASTn (83). Alignment of the isolates and reference sequences was performed with MUSCLE from the Geneious software v.11.0.5 (84). The alignment was trimmed to the common 16S rRNA gene fragment covered by both sets of sequences. Phylogeny was constructed using maximum-likelihood inference with RAXML-NG 0.9.0 (85) and the GTR evolutionary model with optimization in the among-site rate heterogeneity model and the proportion of invariant sites $(\mathrm{GTR}+\mathrm{G}+\mathrm{I})$, and 100 bootstrap replicates. In the same way a phylogenetic tree was constructed with the partial 16S rRNA sequences of the positive isolates only. In this tree the closest match in SILVA v.132 database was also included. Presence of merA and merAB genes, origin of the strains, plus their $\mathrm{MIC}$ to $\mathrm{HgCl}_{2}$ and $\mathrm{MeHg}$ were added with Interactive Tree of Life (ITOL) (86).

On the other hand, phylogenetic trees were also constructed with the amino acid sequences of the amplified merA and merAB genes. As reference sequences we included the best BLASTn hits against UniProtKB sequences retrieved with KEGG identifiers K00520 (merA) and K00221(merB). Sequences were aligned with ClustalW of the Genious software v.11.0.5 (84) with the Gonnet substitution matrix and default gap extension and opening penalties as described previously (29). For merA, the dihydrolipoamide dehydrogenase protein sequences from Magnetospirillum magneticum AMB-1 (WP_011386317.1) and Pseudomonas fluorescens Pf0-1 (WP_011336663.1) served as outgroups. Likewise, we included, only in the alignment, the merA sequence of Streptomyces lividans (P30341), which served to trim the N-terminal region of the aligned sequences such that only the core domain of merA, corresponding to 
positions 1-464 of this Streptomyces lividans remained (87). In the case of merAB, outgroup sequences were not included. Phylogenetic trees were constructed using maximum-likelihood inference with RAXML-NG 0.9.0 (85) and the LG evolutionary model with optimization in the among-site rate heterogeneity model and the proportion of invariant sites $(\mathrm{LG}+\mathrm{G}+\mathrm{I})$, and 100 bootstrap replicates.

\subsection{Minimum inhibitory concentration experiments}

Minimum inhibitory concentration (MIC) assays were designed based on previous studies (65, 88 ) in order to assess the tolerance of the marine strains to different concentrations of inorganic $\mathrm{Hg}$ (as mercury(II) chloride, $\mathrm{HgCl}_{2}$ ) and organic $\mathrm{Hg}$ (as methylmercury chloride, $\mathrm{CH}_{3} \mathrm{HgCl}$ ) and thus, to test the activity of merA and $m e r B$ genes respectively. A stock solution of $\mathrm{HgCl}_{2}$ was prepared at $500 \mu \mathrm{M}$ with autoclaved Milli-Q water. Liquid cultures of the strains growing in Zobell broth with an optical density (O.D. at 600nm) of 0.1 were placed in 24-well plates and inoculated with $5 \mu \mathrm{M}, 10 \mu \mathrm{M}, 20 \mu \mathrm{M}, 25 \mu \mathrm{M}$ and $50 \mu \mathrm{M} \mathrm{HgCl}_{2}$. In specific cases growth was observed in all $\mathrm{HgCl}_{2}$ concentrations and further MIC assays were done increasing the final concentrations to $50 \mu \mathrm{M}, 60 \mu \mathrm{M}, 70 \mu \mathrm{M}, 80 \mu \mathrm{M}, 90 \mu \mathrm{M}$ and $100 \mu \mathrm{M}$. The tolerance to $\mathrm{CH}_{3} \mathrm{HgCl}$ was also tested for the most tolerant strains to $\mathrm{HgCl}_{2}$. In these case, 24-well plates were inoculated with the stock solution to reach final concentrations at $2.5 \mu \mathrm{M}, 5 \mu \mathrm{M}, 10 \mu \mathrm{M}$, $15 \mu \mathrm{M}$ and $20 \mu \mathrm{M}$. In all plates a positive control (liquid culture of the strains not amended with $\mathrm{CH}_{3} \mathrm{HgCl}$ or $\mathrm{HgCl}_{2}$ ) and a negative control (liquid culture of a non-resistant marine strain of the genus Erythrobacter) were included in the assays. Plates were sealed with parafilm and incubated at room temperature (RT, $\sim 20^{\circ} \mathrm{C}$ ) and in the dark for $72 \mathrm{~h}$. Visual lectures and O.D. lectures at $600 \mathrm{~nm}$ were done in a $24 \mathrm{~h}$ period using an automatic plate reader (Infinite ${ }^{\circledR} \mathrm{M} 200$, Tecan) and data was collected using the Magellan ${ }^{\mathrm{TM}}$ Data Analysis Software (Tecan Diagnostics () .

\subsection{Growth curves}

Growth curves were performed to characterize the growth rates of the most tolerant strain (ISS312) to different concentrations of MeHg. We prepared $200 \mathrm{ml}$ of liquid cultures in Zobell broth supplemented with $\mathrm{CH}_{3} \mathrm{HgCl}$ at final concentrations of $0 \mu \mathrm{M}$ (positive control), $1 \mu \mathrm{M}, 2.5$ $\mu \mathrm{M}$ and $5 \mu \mathrm{M}$ in triplicates. The initial O.D. at $600 \mathrm{~nm}$ of the cultures was 0.05 in order to assure enough concentration of cells for growing. Samples for O.D. measurements and for bacterial cell counts were taken approximately every two hours. O.D. was measured at $600 \mathrm{~nm}$ with a spectrophotometer (Varian Cary® 100 UV-Vis) and cells were stained with 4',6diamidino-2-phenylindole (DAPI) and counted with an automated microscope Zeiss Axio 
Imager Z2M (89, 90) using the automated image analysis software ACME Tool (www.technobiology.ch). Predicted growth curves based on O.D. observations and kinetics values (growth rates $\left(\mu_{\max }\right)$, carrying capacity $(\mathrm{k})$ and lag phase time) were calculated with $\mathrm{R}$ package growthcurver v.0.3.0 (91) and GrowthRates v.4.3 software (92). For graphical representation, replicates of the different growth curves experiments at several $\mathrm{MeHg}$ concentrations were averaged. Hence, mean O.D. and standard deviation was calculated for each time point of the curves.

\subsection{Measurement of the biotic and abiotic degradation of $\mathrm{MeHg}$}

In order to characterize the $\mathrm{MeHg}$ degradation rates of our bacteria caused by the action of the merA and merB genes, $2 \mathrm{ml}$ samples were taken from the $1 \mu \mathrm{M}$ and $5 \mu \mathrm{M}$ growth curves of the most tolerant strain, Alteromonas sp. ISS312, at times $0,6,12,24$ and $48 \mathrm{~h}$. Besides, in order to check the possibility that $\mathrm{MeHg}$ was being abiotically removed, we measured the $\mathrm{MeHg}$ concentrations from samples taken from multiwell plates experiments. These included one well of a liquid culture from the ISS312 strain in Zobell broth (initial O.D. at $600 \mathrm{~nm}$ of 0.05) amended with $5 \mu \mathrm{M} \mathrm{CH}_{3} \mathrm{HgCl}$ and incubated at RT during $72 \mathrm{~h}$ in the dark, as well as two different controls to detect the possible abiotic degradation of $\mathrm{MeHg}$ : (i) medium control $\left(\mathrm{CH}_{3} \mathrm{HgCl}\right.$ at concentrations of $1 \mu \mathrm{M}$ and $5 \mu \mathrm{M}$ with no strain added), and (ii) killed control $\left(\mathrm{CH}_{3} \mathrm{HgCl}\right.$ at concentrations of $1 \mu \mathrm{M}$ and $5 \mu \mathrm{M}$ added to autoclaved liquid cultures of the strain). Three replicates of $2 \mathrm{ml}$ samples from each well, containing the $\mathrm{CH}_{3} \mathrm{HgCl}$ treatment and the different controls, were taken at times 0 and $72 \mathrm{~h}$. Collected samples were immediately frozen at $-80{ }^{\circ} \mathrm{C}$. Concentration of $\mathrm{Hg}$ species was measured by direct derivatization of the culture samples with sodium tetraethyl borate and injection into a hyphenated system consisting of a gas chromatograph coupled to an atomic fluorescence detector via pyrolysis (GC-pyroAFS) as previously described elsewhere (93). Briefly, $2 \mathrm{ml}$ samples were used for derivatization. The $\mathrm{pH}$ of the extracts was adjusted to 3.9 by adding $5 \mathrm{ml}$ of $0.1 \mathrm{M}$ acetic acidsodium acetate buffer and ammonia (20\%) if necessary. Then, $2 \mathrm{ml}$ of hexane and $250 \mu \mathrm{l}$ of sodium tetraethyl borate $(6 \%, \mathrm{w} / \mathrm{v})$ were added and the mixture was manually shaken for $5 \mathrm{~min}$. The sample was centrifuged for $5 \mathrm{~min}$ at $600 \mathrm{~g}$. The organic layer was transferred to a chromatographic glass vial and stored at $-18{ }^{\circ} \mathrm{C}$ until analysis. When $\mathrm{Hg}$ species were not detectable, the organic layer was preconcentrated under a gentle stream of nitrogen to a low volume (50-100 $\mu \mathrm{L})$ just before the measurement. The procedural detection limits, after preconcentration, were 0.19 and $0.23 \mathrm{nM}$ for $\mathrm{MeHg}$ and inorganic $\mathrm{Hg}$, respectively.

\subsection{Preparation and observation of samples for transmission electron microscopy}


In order to study potential effects of MeHg on strain ISS312 cells morphology, the isolate was grown separately during $24 \mathrm{~h}$ in Zobell broth not amended with $\mathrm{CH}_{3} \mathrm{HgCl}$ and amended at a final concentration of $5 \mu \mathrm{M}$ with shaking in the dark. The overnight culture was centrifuged at $1000 \mathrm{~g}$ during $15 \mathrm{~min}$ and the supernatant was discarded. The pellet was fixed with paraformaldehyde $2 \%$ final concentration during $30 \mathrm{~min}$ at RT. After fixation, the pellet was processed as previously described (94) to finally obtain thin sections of the samples that were examined by transmission electron microscopy (TEM, JEM-1400 plus, JEOL). Visualizations were done by the microscopy service of the Universitat Autònoma de Barcelona (http://sct.uab.cat/microscopia/en/content/inici).

\subsection{Strain ISS312 genome sequencing}

DNA from strain ISS312 was extracted using the DNeasy Blood \& Tissue kit (Qiagen), following the manufacturer's recommendations. A genome library was prepared with a Celero $^{\mathrm{TM}}$ DNA-seq library system and sequencing was performed with paired-ended $300 \mathrm{bp}$ long reads by IGA-Tech with a MiSeq Illumina machine. The sequence data was filtered to remove the adapters and the unpaired reads with cutadapt v.1.16 (95) and the quality was assessed before and after with fastaqc v.0.11.7. The clean data were used to do the assembly with Spades v.3.12.0 and then optimized with the same program. QUAST v.5.0.1 (96) and ALE were used to assess the quality of the assemblies and the best scores were selected. K-mer 121, 125 and 127 were selected for the optimized-combined assembly and the quality was assessed again. The annotation was done with Prokka v1.13 (97) and the completeness of the genome was checked with CheckM v1.0.18 (98). In order to search for plasmids within our contigs, we used the database PLSDB (99).

\subsection{Fragment recruitment analysis of the genome of strain ISS312 in bathypelagic} metagenomes

The abundance of ISS312 across the global bathypelagic ocean was assessed thanks to its complete genome. Fragment Recruitment Analysis (FRA) was performed by mapping the metagenomic reads of 58 bathypelagic microbial metagenomes from 32 stations (100) from Malaspina Expedition, including free-living $(0.2-0.8 \mu \mathrm{m})$ and particle-attached $(0.8-20 \mu \mathrm{m})$ bacterial communities. Analysis were done with BLASTn v2.7.1+ (83) using the following alignment parameters: -perc_identity 70, -evalue 0.0001. Only those reads with more than $90 \%$ coverage and mapping identity equal to or higher than $95 \%$ were kept for analysis. In order to remove possible false mapping hits to the conserved regions of rRNA genes, reads aligning to 
the regions annotated as ribosomal genes were not considered for the analysis. Read counts from mapped reads from each metagenome were corrected by their sequencing depth to make them comparable through samples.

\subsection{Statistical analyses}

ANOVA tests from the stats package of the R Statistical Software (101) was applied in order to observe possible differences between oceanographic regions in terms of number of positive strains harboring $m e r A$ and/or $m e r A B$ genes. To assess significance, the statistical analyses were set to a conservative alpha value of 0.05 . Further, non-parametric Kruskal-Wallis test, from the stats package of the R Statistical Software, (101) was applied followed by the post hoc pairwise Wilcox test to see the differences between FRA results in different oceanographic regions and between free-living and particle-attached bacterial communities. To assess significance, the statistical analyses were set to a conservative alpha value of 0.05 .

\subsection{Nucleotide accession numbers}

Mercury detoxification genes (merA and merAB) detected in this study through PCR are deposited in GenBank under accession numbers MW273028 - MW273125. Alteromonas mediterranea ISS312 genome was deposited in ENA under study accession number PRJEB46669.

\section{References}

1. M. W. Miller, T. W. Clarkson, Mercury, mercurial, and mercaptans. (Thomas, Springfield, ILL., 1973).

2. T. W. Clarkson, Mercury: major issues in environmental health. Environ. Health Perspect. 100, 31-38 (1993).

3. H. M. Amos, D. J. Jacob, D. G. Streets, E. M. Sunderland, Legacy impacts of alltime anthropogenic emissions on the global mercury cycle. Global Biogeochem. Cycles. 27, 410-421 (2013).

4. UN-Environment, 2019. Global Mercury Assessment 2018. UN-Environment Programme, Chemicals and Health Branch, Geneva, Switzerland. 59 pp.

5. H. H. Eriksen, F. X. Perrez, The Minamata convention: A comprehensive response to a global problem. Rev. Eur. Comp. Int. Environ. Law. 23, 195-210 (2014).

6. A. Saiz-Lopez, S. P. Sitkiewicz, D. Roca-Sanjuán, J. M. Oliva-Enrich, J. Z. Dávalos, R. Notario, M. Jiskra, Y. Xu, F. Wang, C. P. Thackray, E. M. 
Sunderland, D. J. Jacob, O. Travnikov, C. A. Cuevas, A. U. Acuña, D. Rivero, J. M. C. Plane, D. E. Kinnison, J. E. Sonke, Photoreduction of gaseous oxidized mercury changes global atmospheric mercury speciation, transport and deposition. Nat. Commun. 9, 4796 (2018).

7. M. Enrico, G. Le Roux, N. Marusczak, L.-E. Heimbürger, A. Claustres, X. Fu, R. Sun, J. E. Sonke, Atmospheric mercury transfer to peat bogs dominated by gaseous elemental mercury dry deposition. Environ. Sci. Technol. 50, 2405-2412 (2016).

8. R. P. Mason, G.-R. Sheu, Role of the ocean in the global mercury cycle. Global Biogeochem. Cycles. 16, 1093 (2002).

9. I. Lehnherr, V. L. St. Louis, H. Hintelmann, J. L. Kirk, Methylation of inorganic mercury in polar marine waters. Nat. Geosci. 4, 298-302 (2011).

10. K. M. Munson, C. H. Lamborg, R. M. Boiteau, M. A. Saito, Dynamic mercury methylation and demethylation in oligotrophic marine water. Biogeosciences. 15, 6451-6460 (2018).

11. M. Monperrus, E. Tessier, D. Amouroux, A. Leynaert, P. Huonnic, O. F. X. Donard, Mercury methylation, demethylation and reduction rates in coastal and marine surface waters of the Mediterranean Sea. Mar. Chem. 107, 49-63 (2007).

12. M. Podar, C. C. Gilmour, C. C. Brandt, A. Soren, S. D. Brown, B. R. Crable, A. V. Palumbo, A. C. Somenahally, D. A. Elias, Global prevalence and distribution of genes and microorganisms involved in mercury methylation. Sci. Adv. 1, e1500675 (2015).

13. C. M. Gionfriddo, M. T. Tate, R. R. Wick, M. B. Schultz, A. Zemla, M. P. Thelen, R. Schofield, D. P. Krabbenhoft, K. E. Holt, J. W. Moreau, Microbial mercury methylation in Antarctic sea ice. Nat. Microbiol. 1, 16127 (2016).

14. R. P. Mason, A. L. Choi, W. F. Fitzgerald, C. R. Hammerschmidt, C. H. Lamborg, A. L. Soerensen, E. M. Sunderland, Mercury biogeochemical cycling in the ocean and policy implications. Environ. Res. 119, 101-117 (2012).

15. G. Harding, J. Dalziel, P. Vass, Bioaccumulation of methylmercury within the marine food web of the outer Bay of Fundy, Gulf of Maine. PLoS One. 13, e0197220 (2018).

16. D. Mergler, H. A. Anderson, L. H. M. Chan, K. R. Mahaffey, M. Murray, M. Sakamoto, A. H. Stern, Methylmercury exposure and health effects in humans: A worldwide concern. Ambio. 36, 3-11 (2007).

17. M. R. Karagas, A. L. Choi, E. Oken, M. Horvat, R. Schoeny, E. Kamai, W. Cowell, P. Grandjean, S. Korrick, Evidence on the human health effects of lowlevel methylmercury exposure. Environ. Health Perspect. 120, 799-806 (2012).

18. D. Cossa, B. Averty, N. Pirrone, The origin of methylmercury in open Mediterranean waters. Limnol. Oceanogr. 54, 837-844 (2009).

19. E. M. Sunderland, D. P. Krabbenhoft, J. W. Moreau, S. A. Strode, W. M. Landing, Mercury sources, distribution, and bioavailability in the North Pacific Ocean: Insights from data and models. Global Biogeochem. Cycles. 23, GB2010 (2009).

20. J. D. Blum, B. N. Popp, J. C. Drazen, C. Anela Choy, M. W. Johnson, Methylmercury production below the mixed layer in the North Pacific Ocean. Nat. Geosci. 6, 879-884 (2013).

21. C. R. Hammerschmidt, K. L. Bowman, Vertical methylmercury distribution in the subtropical North Pacific Ocean. Mar. Chem. 132-133, 77-82 (2012).

22. E. G. Malcolm, J. K. Schaefer, E. B. Ekstrom, C. B. Tuit, A. Jayakumar, H. Park, B. B. Ward, F. M. M. Morel, Mercury methylation in oxygen deficient zones of 
the oceans: No evidence for the predominance of anaerobes. Mar. Chem. 122, 11-19 (2010).

23. C. H. Lamborg, C. R. Hammerschmidt, K. L. Bowman, An examination of the role of particles in oceanic mercury cycling. Philos. Trans. R. Soc. A. 374, 20150297 (2016).

24. T. Zhang., H. Hsu-Kim, Photolytic degradation of methylmercury enhanced by binding to natural organic ligands Tong. Nat. Geosci. 3, 473-476 (2010).

25. P. Seller, C. A. Kelly, J. W. M. Rudd, A. R. Mac Hutchon, Photodegradation of methylmercury in lakes. Nature. 380, 694-697 (1996).

26. M. Costa, P. S. Liss, Photoreduction of mercury in sea water and its possible implications for Hg0 air-sea fluxes. Mar. Chem. 68, 87-95 (1999).

27. L. J. Stal, M. S. Cretoiu, Chapter 1 . What is so special about marine microorganisms? Introduction to the marine microbiome - from diversity to biotechnological applications in The Marine Microbiome (Springer, Switzerland, 2016). pp.3-20.

28. T. Barkay, S. M. Miller, A. O. Summers, Bacterial mercury resistance from atoms to ecosystems. FEMS Microbiol. Rev. 27, 355-384 (2003).

29. E. S. Boyd, T. Barkay, The mercury resistance operon: From an origin in a geothermal environment to an efficient detoxification machine. Front. Microbiol. 3, 349 (2012).

30. R. S. Oremland, C. W. Culbertson, M. R. Winfrey, Methylmercury decomposition in sediments and bacterial cultures: involvement of methanogens and sulfate reducers in oxidative demethylation. Appl. Environ. Microbiol. 57, 130-137 (1991).

31. K. L. Bowman, R. E. Collins, A. M. Agather, C. H. Lamborg, C. R. Hammerschmidt, D. Kaul, C. L. Dupont, G. A. Christensen, D. A. Elias, Distribution of mercury-cycling genes in the Arctic and equatorial Pacific Oceans and their relationship to mercury speciation. Limnol. Oceanogr. 65, S310-S320 (2019).

32. F. Wang, R. W. Macdonald, D. A. Armstrong, G. A. Stern, Total and methylated mercury in the Beaufort Sea: The role of local and recent organic remineralization. Environmetal Sci. Technol. 46, 11821-11828 (2012).

33. L.-E. Heimbürger, D. Cossa, J.-C. Marty, C. Migon, B. Averty, A. Dufour, J. Ras, Methyl mercury distributions in relation to the presence of nano- and picophytoplankton in an oceanic water column (Ligurian Sea, North-western Mediterranean). Geochim. Cosmochim. Acta. 74, 5549-5559 (2010).

34. B. Gworek, O. Bemowska-Kałabun, M. Kijeńska, J. Wrzosek-Jakubowska, Mercury in Marine and Oceanic Waters-a Review. Water, Air, Soil Pollut. 227, 371 (2016).

35. I. Sanz-Sáez, G. Salazar, P. Sánchez, E. Lara, M. Royo-Llonch, E. L. Sà, T. Lucena, M. J. Pujalte, D. Vaqué, C. M. Duarte, J. M. Gasol, C. Pedrós-Alió, O. Sánchez, S. G. Acinas, Diversity and distribution of marine heterotrophic bacteria from a large culture collection. BMC Microbiol. 20, 207 (2020).

36. K. Nakamura, J. Aoki, M. Yamamoto, Mercury volatilization by the most mercury-resistant bacteria from the seawater of Minamata Bay in various physiological conditions. Clean Prod. Process. 2, 174-178 (2000).

37. J. De, N. Ramaiah, Characterization of marine bacteria highly resistant to mercury exhibiting multiple resistances to toxic chemicals. Ecol. Indic. 7, 511520 (2007).

38. W. Zhang, L. Chen, D. Liu, Characterization of a marine-isolated mercury- 
resistant Pseudomonas putida strain SP1 and its potential application in marine mercury reduction. Appl. Microbiol. Biotechnol. 93, 1305-1314 (2012).

39. M. Jayaprakashvel, S. Vijay, C. P. Karthigeyan, A. J. Hussain, Isolation and characterization of mercury resistant bacteria from the coastal are of Chennai, India. Int. J. Adv. Res. 4, 64-76 (2015).

40. H.-H. Chiu, W. Y. Shieh, S. Y. Lin, C.-M. Tseng, P.-W. Chiang, I. Wagner-Dö Bler, Alteromonas tagae sp. nov. and Alteromonas simiduii sp. nov., mercuryresistant bacteria isolated from a Taiwanese estuary. Int. J. Syst. Evol. Microbiol. 57, 1209-1216 (2007).

41. X. Deng, P. Wang, Isolation of marine bacteria highly resistant to mercury and their bioaccumulation process. Bioresour. Technol. 121, 342-347 (2012).

42. G. O. Oyetibo, S. T. Ishola, W. Ikeda-Ohtsubo, K. Miyauchi, M. O. Ilori, G. Endo, Mercury bioremoval by Yarrowia strains isolated from sediments of mercury-polluted estuarine water. Appl. Microbiol. Biotechnol. 99, 3651-3657 (2015).

43. C. Vetriani, Y. S. Chew, S. M. Miller, J. Yagi, J. Coombs, R. A. Lutz, T. Barkay, Mercury adaptation among bacteria from a deep-sea hydrothermal vent. Appl. Environ. Microbiol. 71, 220-226 (2005).

44. K. Nakamura, M. Iwahara, K. Furukawa, Screening of organomercurialvolatilizing bacteria in the mercury-polluted sediments and seawater of Minamata Bay in Japan. Clean Prod. Process. 3, 104-107 (2001).

45. A. A. Lima de Silva, M. A. R. de Carvalho, S. A. L. de Souza, P. M. . T. Dias, R. G. da Silva Filho, C. S. de Meirelles Saramago, C. A. de Melo Bento, E. Hofer, Heavy metal tolerance ( $\mathrm{Cr}, \mathrm{Ag}$ AND $\mathrm{Hg}$ ) in bacteria isolated from sewage.

Brazilian J. Microbiol. 43, 1620-1631 (2012).

46. B. H. Olson, T. Barkay, R. R. Colwell, Role of plasmids in mercury transformation by bacteria isolated from the aquatic environment. Appl. Environ. Microbiol. 38, 478-485 (1979).

47. T. Barkay, Adaptation of aquatic microbial communities to Hg stress. Appl. Environ. Microbiol. 53, 2725-2732 (1987).

48. J. Simbahan, E. Kurth, J. Schelert, A. Dillman, E. Moriyama, S. Jovanovich, P. Blum, Community analysis of a mercury hot spring supports occurrence of domain-specific forms of mercuric reductase. Appl. Environ. Microbiol. 71, 8836-8845 (2005).

49. L. D. Rasmussen, C. Zawadsky, S. J. Binnerup, G. Oregaard, S. J. Sørensen, N. Kroer, Cultivation of hard-to-culture subsurface mercury-resistant bacteria and discovery of new merA gene sequences. Appl. Environ. Microbiol. 74, 37953803 (2008).

50. M. Zeyaullah, B. Islam, A. Ali, Isolation, identification and PCR amplification of merA gene from highly mercury polluted Yamuna river. African J. Biotechnol. 9, 3510-3514 (2009).

51. M. O. Fashola, V. M. Ngole-Jeme, O. O. Babalola, Heavy metal pollution from gold mines: Environmental effects and bacterial strategies for resistance. Int. J. Environ. Res. Public Health. 13, 1047 (2016).

52. A. Ciok, K. Budzik, M. K. Zdanowski, J. Gawor, J. Grzesiak, P. Decewicz, R. Gromadka, D. Bartosik, L. Dziewit, Plasmids of psychrotolerant polaromonas spp. isolated From Arctic and Antarctic glaciers - diversity and role in adaptation to polar environments. Front. Microbiol. 9, 1285 (2018).

53. J. De, N. Ramaiah, A. Mesquita, X. N. Verlekar, Tolerance to various toxicants by marine bacteria highly resistant to mercury. Mar. Biotechnol. 5, 185-193 
(2003).

54. A. K. Møller, T. Barkay, M. A. Hansen, A. Norman, L. H. Hansen, S. J.

Sørensen, E. S. Boyd, N. Kroer, Mercuric reductase genes (merA) and mercury resistance plasmids in High Arctic snow, freshwater and sea-ice brine. FEMS Microbiol. Ecol. 87, 52-63 (2014).

55. L. Baumann, P. Baumann, M. Mandel, R. D. Allen, Taxonomy of aerobic marine eubacteria. J. Bacteriol. 110, 402-429 (1972).

56. H. Eilers, J. Pernthaler, F. O. Glöckner, R. Amann, Culturability and in situ abundance of pelagic Bacteria from the North Sea. Appl. Environ. Microbiol. 66, 3044-3051 (2000).

57. M. M. Floyd, J. Tang, M. Kane, D. Emerson, Captured diversity in a culture collection: case study of the geographic and habitat distributions of environmental isolates held at the american type culture collection. Appl. Environ. Microbiol. 71, 2813-2823 (2005).

58. A. Gärtner, M. Blümel, J. Wiese, J. F. Imhoff, Isolation and characterisation of bacteria from the Eastern Mediterranean deep sea. Antonie van Leeuwenhoek, Int. J. Gen. Mol. Microbiol. 100, 421-435 (2011).

59. K. M. Handley, J. R. Lloyd, Biogeochemical implications of the ubiquitous colonization of marine habitats and redox gradients by Marinobacter species. Front. Microbiol. 4, 136 (2013).

60. I. Lekunberri, J. M. Gasol, S. G. Acinas, L. Gómez-Consarnau, B. G. Crespo, E. O. Casamayor, R. Massana, C. Pedrós-Alió, J. Pinhassi, The phylogenetic and ecological context of cultured and whole genome-sequenced planktonic bacteria from the coastal NW Mediterranean Sea. Syst. Appl. Microbiol. 37, 216-228 (2014).

61. W. Kai, Y. Peisheng, M. Rui, J. Wenwen, S. Zongze, Diversity of culturable bacteria in deep-sea water from the South Atlantic Ocean. Bioengineered. 8, 572-584 (2017).

62. E. Singer, E. A. Webb, W. C. Nelson, J. F. Heidelberg, N. Ivanova, A. Pati, K. J. Edwards, Genomic potential of Marinobacter aquaeolei, a biogeochemical “opportunitroph.” Appl. Environ. Microbiol. 77, 2763-2771 (2011).

63. M. López-Pérez, A. Gonzaga, A.-B. Martin-Cuadrado, O. Onyshchenko, A. Ghavidel, R. Ghai, F. Rodriguez-Valera, Genomes of surface isolates of Alteromonas macleodii: the life of a widespread marine opportunistic copiotroph. Sci. Rep. 2, 696 (2012).

64. K. M. Fontanez, J. M. Eppley, T. J. Samo, D. M. Karl, E. F. DeLong, Microbial community structure and function on sinking particles in the North Pacific Subtropical Gyre. Front. Microbiol. 6, 469 (2015).

65. E. Ivars-Martinez, A.-B. Martin-Cuadrado, G. D'Auria, A. Mira, S. Ferriera, J. Johnson, R. Friedman, F. Rodriguez-Valera, Comparative genomics of two ecotypes of the marine planktonic copiotroph Alteromonas macleodii suggests alternative lifestyles associated with different kinds of particulate organic matter. ISME J. 2, 1194-1212 (2008).

66. B. V. Mathema, B. C. Thakuri, M. Sillanpää, Bacterial mer operon-mediated detoxification of mercurial compounds: a short review. Arch. Microbiol. 193, 837-844 (2011).

67. J. K. Schaefer, J. Yagi, J. R. Reinfelder, T. Cardona, K. M. Ellickson, S. Tel-Or, T. Barkay, Role of the bacterial organomercury lyase (MerB) in controlling methylmercury accumulation in mercury-contaminated natural waters. Environ. Sci. Technol. 38, 4304-4311 (2004). 
68. D. Cossa, L.-E. Heimbürger, D. Lannuzel, S. R. Rintoul, E. C. V. Butler, A. R. Bowie, B. Averty, R. J. Watson, T. Remenyi, Mercury in the Southern Ocean. Geochim. Cosmochim. Acta. 75, 4037-4052 (2011).

69. R. K. Math, H. M. Jin, J. M. Kim, Y. Hahn, W. Park, E. L. Madsen, C. O. Jeon, Comparative genomics reveals adaptation by Alteromonas sp. SN2 to marine tidal-flat conditions: Cold tolerance and aromatic hydrocarbon metabolism. PLoS One. 7, e35784 (2012).

70. H. G. Griffin, T. J. Foster, S. Silver, T. K. Misra, Cloning and DNA sequence of the mercuric- and organomercurial-resistance determinants of plasmid pDU1358. Proc. Natl. Acad. Sci. U. S. A. 84, 3112-3116 (1987).

71. S. Mindlin, G. Kholodii, Z. Gorlenko, S. Minakhina, L. Minakhin, E. Kalyaeva, A. Kopteva, M. Petrova, O. Yurieva, V. Nikiforov, Mercury resistance transposons of Gram-negative environmental bacteria and their classification. Res. Microbiol. 152, 811-822 (2001).

72. A. M. Osborn, K. D. Bruce, P. Strike, D. A. Ritchie, Distribution, diversity and evolution of the bacterial mercury resistance (mer) operon. FEMS Microbiol. Rev. 19, 239-262 (1997).

73. L. Bass, C. A. Liebert, M. D. Lee, A. O. Summers, D. G. White, S. G. Thayer, J. J. Maurer, Incidence and characterization of integrons, genetic elements mediating multiple-drug resistance, in avian Escherichia coli. Antimicrob. Agents Chemother. 43, 2925-2929 (1999).

74. M. Harada, K. Ito, N. Nakajima, S. Yamamura, M. Tomita, H. Suzuki, S. Amachi, Genomic analysis of Pseudomonas sp. strain SCT, an iodate-reducing bacterium isolated from marine sediment, reveals a possible use for bioremediation. G3. 9, 1321-1329 (2019).

75. A. K. Møller, T. Barkay, W. A. Al-Soud, S. J. Sørensen, H. Skov, N. Kroer, Diversity and characterization of mercury-resistant bacteria in snow, freshwater and sea-ice brine from the High Arctic. FEMS Microbiol. Ecol. 75, 390-401 (2011).

76. K. Morishita, K. Nakamura, K. Tuchiya, K. Nishimura, M. Iwahara, O. Yagi, Removal of methylmercury from a fish broth by Alteromonas macledii isolated from Minamata Bay. Japanese J. Water Treat. Biol. 42, 45-51 (2006).

77. C. Lamborg, K. Bowman, C. Hammerschmidt, C. Gilmour, K. Munson, N. Selin, C. M. Tseng, Mercury in the anthropocene ocean. Oceanography. 27, 76-87 (2014).

78. R. Zheng, S. Wu, N. Ma, C. Sun, Genetic and physiological adaptations of marine bacterium Pseudomonas stutzeri 273 to mercury stress. Front. Microbiol. 9, 682 (2018).

79. J. B. Robinson, O. H. Tuovinen, Mechanisms of microbial resistance and detoxification of mercury and organomercury compounds: physiological, biochemical, and genetic analyses. Microbiol. Rev. 48, 95-124 (1984).

80. K. Saranya, A. Sundaramanickam, S. Shekhar, S. Swaminathan, T. Balasubramanian, Bioremediation of mercury by Vibrio fluvialis screened from industrial effluents. Biomed Res. Int. 2017, 6509648 (2017).

81. M. Mestre, C. Ruiz-González, R. Logares, C. M. Duarte, J. M. Gasol, M. M. Sala, Sinking particles promote vertical connectivity in the ocean microbiome. Proc. Natl. Acad. Sci. U. S. A. 115, E6799-E6807 (2018).

82. M. Kanehisa, S. Goto, KEGG: kyoto encyclopedia of genes and genomes. Nucleic Acids Res. 28, 27-30 (2000).

83. S. F. Altschul, W. Gish, W. Miller, E. W. Myers, D. J. Lipman, Basic local 
alignment search tool. J. Mol. Biol. 215, 403-410 (1990).

84. M. Kearse, R. Moir, A. Wilson, S. Stones-Havas, M. Cheung, S. Sturrock, S. Buxton, S. Cooper, S. Markowitz, C. Duran, T. Thierer, B. Ashton, P. Meinties, A. Drummond, Geneious Basic: an integrated and extendable desktop software platform for the organization and analysis of sequence data. Bioinformatics. 28, 1647-1649 (2012).

85. A. M. Kozlov, D. Darriba, T. Flouri, B. Morel, A. Stamatakis, RAxML-NG: a fast, scalable and user-friendly tool for maximum likelihood phylogenetic inference. Bioinformatics. 35, 4453-4455 (2019).

86. I. Letunic, P. Bork, Interactive Tree Of Life (iTOL) v4: recent updates and new developments. Nucleic Acids Res. 47, W256-W259 (2019).

87. T. Barkay, K. Kritee, E. Boyd, G. Geesey, A thermophilic bacterial origin and subsequent constraints by redox, light and salinity on the evolution of the microbial mercuric reductase. Environ. Microbiol. 12, 2904-2917 (2010).

88. I. Wiegand, K. Hilpert, R. E. W. Hancock, Agar and broth dilution methods to determine the minimal inhibitory concentration (MIC) of antimicrobial substances. Nat. Protoc. 3, 163-175 (2008).

89. M. Zeder, A. Ellrott, R. Amann, Automated sample area definition for highthroughput microscopy. Cytom. Part A. 79A, 306-310 (2011).

90. M. Zeder, J. Pernthaler, Multispot live-image autofocusing for high-throughput microscopy of fluorescently stained bacteria. Cytom. Part A. 75A, 781-788 (2009).

91. K. Sprouffske, A. Wagner, Growthcurver: an R package for obtaining interpretable metrics from microbial growth curves. BMC Bioinformatics. 17, 172 (2016).

92. B. G. Hall, H. Acar, A. Nandipati, M. Barlow, Growth rates made easy. Mol. Biol. Evol, 232-238 (2014).

93. J. J. Berzas Nevado, R. C. Rodríguez Martín-Doimeadios, E. M. Krupp, F. J. Guzmán Bernardo, N. Rodríguez Fariñas, M. Jiménez Moreno, D. Wallace, M. J. Patiño Ropero, Comparison of gas chromatographic hyphenated techniques for mercury speciation analysis. J. Chromatogr. A. 1218, 4545-4551 (2011).

94. C. Lee, J. Y. Kim, W. Il Lee, K. L. Nelson, J. Yoon, D. L. Sedlak, Bactericidal effect of zero-valent iron nanoparticles on Escherichia coli. Environ. Sci. Technol. 42, 4927-4933 (2008).

95. M. Martin, Cutadapt removes adapter sequences from high-throughput sequencing reads. EMBnet.journal. 17, 10-12 (2021).

96. A. Gurevich, V. Saveliev, N. Vyahhi, G. Tesler, QUAST: quality assessment tool for genome assemblies. Bioinformatics. 29, 1072-1075 (2013).

97. T. Seemann, Prokka: rapid prokaryotic genome annotation. Bioinformatics. 30, 2068-2069 (2014).

98. D. H. Parks, M. Imelfort, C. T. Skennerton, P. Hugenholtz, G. W. Tyson, CheckM: assessing the quality of microbial genomes recovered from isolates, single cells, and metagenomes. Genome Res. 25, 1043-1055 (2015).

99. V. Galata, T. Fehlmann, C. Backes, A. Keller, PLSDB: a resource of complete bacterial plasmids. Nucleic Acids Res. 47, D195-D202 (2019).

100. C. M. Duarte, Seafaring in the 21St Century: The Malaspina 2010 Circumnavigation Expedition. Limnol. Oceanogr. Bull. 24, 11-14 (2015).

101. R core team, $\mathrm{R}$ core team. A language and environment for statistical computing. $\mathrm{R}$ foundation for statistical computing, Vienna, Austria https://www.R-project. org/ (2017). 


\section{Acknowledgements}

We are grateful to Elisabet Laia Sà for helping in the laboratory. We thank the Spanish ministry of Science, Innovation and Universities for granting ISS with a PhD FPU grant (FPU14/03590). We are also grateful to the MER_CLUB project (863584-MER_CLUB-EMFF-BlueEconomy2018) for hiring ISS in order to finish this study.

\section{Funding:}

This study was supported by grants:

MER_CLUB (863584-MER_CLUB-EMFF-BlueEconomy-2018) from the European

Commission to SGA and OS. Marie Curie Individual Fellowship (H2020-MSCA-IF-2016;

project-749645) to AGB.

\section{Author contributions:}

Conceptualization: ISS, SGA, OS

Experimental procedures: ISS, CPG, LT, MPiF, MC, RCRM-D

Data analyses: ISS, PS

Supervision: SGA, OS

Writing: ISS, AGB, SGA, OS

Competing interests: Authors declare that they have no competing interests.

Data and materials availability: Mercury detoxification genes (merA and merAB) detected in this study through PCR are deposited in GenBank under accession numbers MW273028 MW273125. Alteromonas mediterranea ISS312 genome was deposited in ENA under study accession number PRJEB46669. 


\section{Tables}

Table 1. Summary of the PCR screening results for merA and merAB in Alteromonas and Marinobacter strains. Photic includes surface and deep chlorophyll maximum (DCM) isolates, while aphotic includes bathypelagic isolates.

\begin{tabular}{|c|c|c|c|c|c|}
\hline \multirow{2}{*}{ Genus } & \multirow{2}{*}{ Layer } & \multirow{2}{*}{$\mathbf{N}^{\mathbf{0}}$ of tested strains } & \multicolumn{2}{|c|}{ Positives PCR for } & \multirow{2}{*}{\begin{tabular}{c} 
Total strains with \\
\cline { 3 - 5 }
\end{tabular}} \\
\cline { 3 - 5 } merA and/or merAB
\end{tabular}


Table 2. Characteristics of the marine seawater samples from five different cruises used for the isolation of bacteria screened for Hg resistance genes. ATP09: Arctic Tipping Points cruise in 2009; BBMO: Blanes Bay Microbial Observatory.

\begin{tabular}{|c|c|c|c|c|c|c|c|c|}
\hline Cruise & Station & Oceanic location & Latitude & Longitude & $\begin{array}{c}\text { Depth } \\
\text { (m) }\end{array}$ & $\begin{array}{c}\mathrm{N}^{0} \text { of } \\
\text { screened } \\
\text { isolates }\end{array}$ & $\begin{array}{c}\mathrm{N}^{0} \text { of } \\
\text { merA } \\
\text { positives }\end{array}$ & $\begin{array}{c}\mathrm{N}^{0} \text { of } \\
\text { mer } A B \\
\text { positives }\end{array}$ \\
\hline \multirow{7}{*}{$\begin{array}{c}\text { Tara } \\
\text { Oceans }\end{array}$} & ST 39 & Indian Ocean & $18^{\circ} 35.2^{\prime} \mathrm{N}$ & $66^{\circ} 28.22^{\prime} \mathrm{E}$ & 25 & 44 & 0 & 1 \\
\hline & ST 67 & South Atlantic & $32^{\circ} 17.31^{\prime} \mathrm{S}$ & $17^{\circ} 12.22^{\prime} \mathrm{E}$ & 5 & 20 & 11 & 6 \\
\hline & ST 72 & South Atlantic & $8^{\circ} 46.44^{\prime} \mathrm{S}$ & $17^{\circ} 54.36^{\prime} \mathrm{W}$ & 5 & 15 & 4 & 2 \\
\hline & ST 76 & South Atlantic & $20^{\circ} 56.7^{\prime} \mathrm{S}$ & $35^{\circ} 10.49^{\prime} \mathrm{W}$ & 5 & 31 & 15 & 8 \\
\hline & ST 85 & Southern Ocean & $62^{\circ} 2.19^{\prime} \mathrm{S}$ & $49^{\circ} 31.44^{\prime} \mathrm{W}$ & 5.9 & 1 & 1 & 0 \\
\hline & ST 85 & Southern Ocean & $62^{\circ} 2.19^{\prime} \mathrm{S}$ & $49^{\circ} 31.44^{\prime} \mathrm{W}$ & 87.4 & 6 & 4 & 4 \\
\hline & ST 151 & North Atlantic & $36^{\circ} 10.17^{\prime} \mathrm{N}$ & $29^{\circ} 1.23^{\prime} \mathrm{W}$ & 5 & 31 & 6 & 0 \\
\hline \multirow{2}{*}{ ATP09 } & AR_1 & Arctic Ocean & $78^{\circ} 20.00^{\prime} \mathrm{N}$ & $15^{\circ} 00.00^{\prime} \mathrm{E}$ & 2 & 3 & 0 & 0 \\
\hline & AR_2 & Arctic Ocean & $76^{\circ} 28.65^{\prime} \mathrm{N}$ & $28^{\circ} 00.62^{\prime} \mathrm{E}$ & 25 & 4 & 0 & 0 \\
\hline \multirow{6}{*}{ Malaspina } & ST 10 & North Atlantic & $21^{\circ} 33.36^{\prime} \mathrm{N}$ & $23^{\circ} 26^{\prime} \mathrm{W}$ & 4002 & 11 & 1 & 0 \\
\hline & ST 17 & South Atlantic & $3^{\circ} 1.48^{\prime} \mathrm{S}$ & $27^{\circ} 19.48^{\prime} \mathrm{W}$ & 4002 & 3 & 2 & 0 \\
\hline & ST 23 & South Atlantic & $15^{\circ} 49.48^{\prime} \mathrm{S}$ & $33^{\circ} 24.36^{\prime} \mathrm{W}$ & 4003 & 13 & 5 & 0 \\
\hline & ST 32 & South Atlantic & $26^{\circ} 56.8^{\prime} \mathrm{S}$ & $21^{\circ} 24^{\prime} \mathrm{W}$ & 3200 & 14 & 7 & 0 \\
\hline & ST 33 & South Atlantic & $27^{\circ} 33.2^{\prime} \mathrm{S}$ & $18^{\circ} 5.4^{\prime} \mathrm{W}$ & 3904 & 2 & 2 & 2 \\
\hline & ST 43 & South Atlantic & $32^{\circ} 48.8^{\prime} \mathrm{S}$ & $12^{\circ} 46.2^{\prime} \mathrm{E}$ & 4000 & 3 & 3 & 2 \\
\hline MIFASOL & ST 8 & NW Mediterranean & $40^{\circ} 38.41^{\prime} \mathrm{N}$ & $2^{\circ} 50^{\prime} \mathrm{E}$ & 2000 & 84 & 9 & 2 \\
\hline BBMO & IBSURF & NW Mediterranean & $41^{\circ} 40^{\prime} \mathrm{N}$ & $2^{\circ} 48^{\prime} \mathrm{E}$ & 5 & 5 & 2 & 0 \\
\hline
\end{tabular}




\section{$1 \quad$ Figures \\ 2}

3

A)

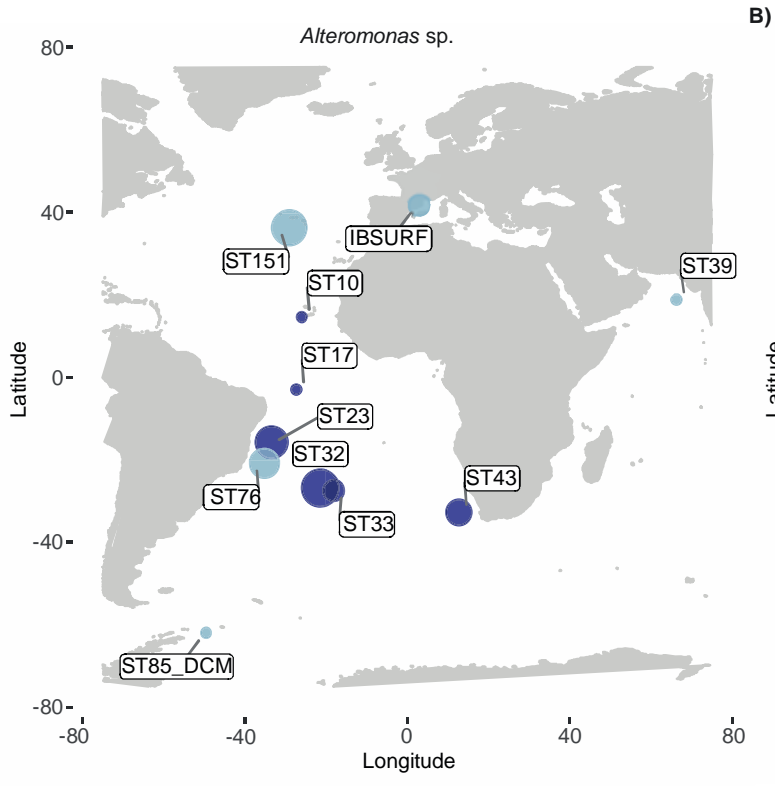

B)
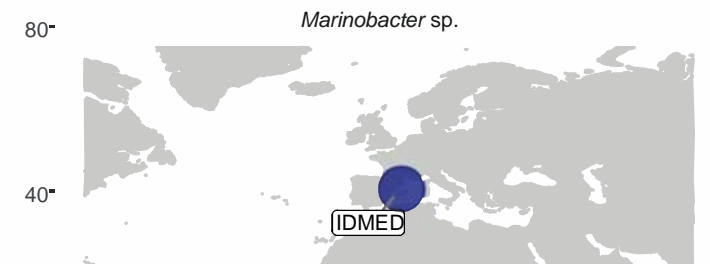

$40-$

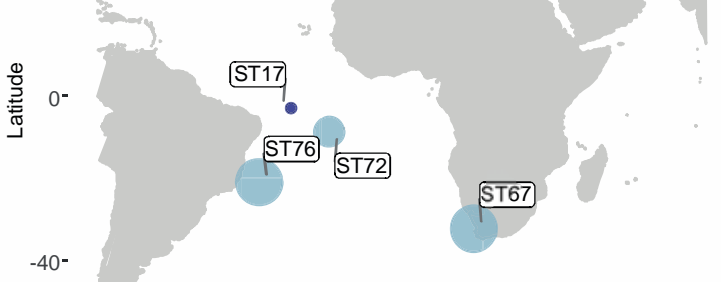

$-80$.

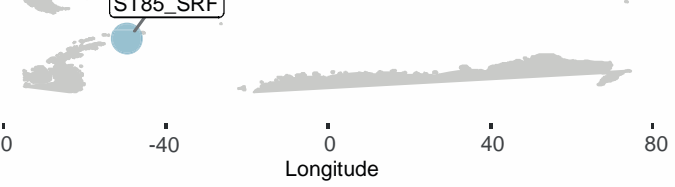

Layer

- SRF ODE

Figure 1. Distribution of the positive strains after functional screening for merA and/or merAB genes. (A) Alteromonas sp. strains (B) Marinobacter sp. strains. Size of the dots indicates how many strains per station including merA and/or merAB were identified. Color of the dots indicated the layer (photic or bathypelagic) where the strains were retrieved. 
bioRxiv preprint doi: https://doi.org/10.1101/2021.08.09.455674; this version posted August 10,2021. The copyright holder for this preprint (which was not certified by peer review) is the author/funder, who has granted bioRxiv a license to display the preprint in perpetuity. It is made available under aCC-BY-NC-ND 4.0 International license.

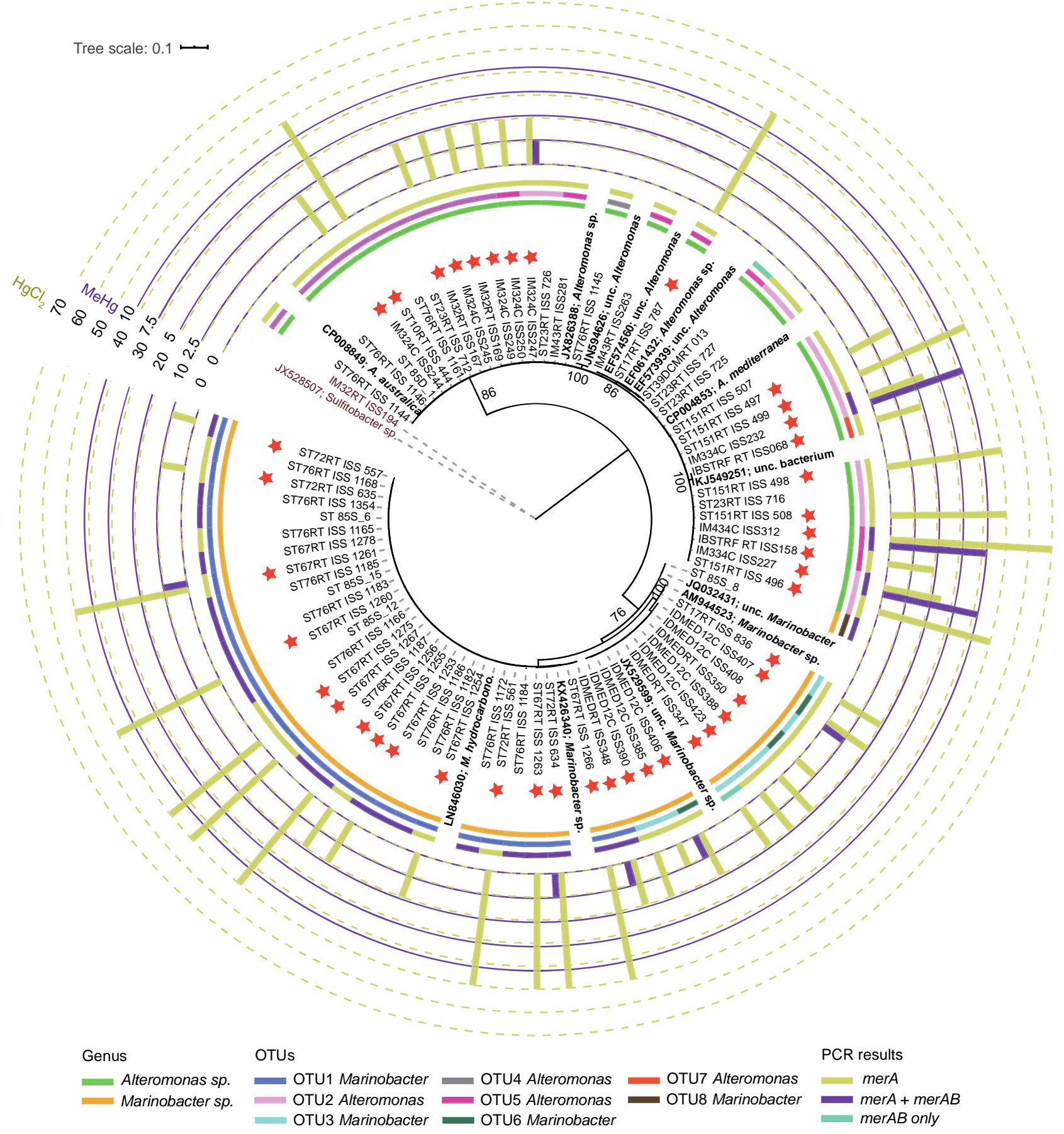

Figure 2. Phylogeny of the 16S rRNA gene of Alteromonas and Marinobacter positive strains for merA and/or merAB genes screening. First inner colored strip indicates genus of the strain. Second colored strip indicates to which OTU (99\% sequence similarity in their $16 \mathrm{~S}$ rRNA gene) each of the strains belong. Third colored strip indicates presence or absence of genes based on PCR results. Red stars indicate those isolates where MIC experiments where performed. Bars indicate results from the MIC experiments: yellow, $\mathrm{HgCl}_{2}$; purple, $\mathrm{MeHg}$. Tolerance values are in $\mu$ M. JX52807, Sulfitobacter and IM32RT_ISS194 are outgroups of the tree. The numbers in the nodes represent bootstrap percentages $>75 \%$. A. australica, Alteromonas australica; A. mediterranea, Alteromonas mediterranea; unc., uncultured; $M$. hydrocarbon., Marinobacter hydrocarbonoclasticus. 


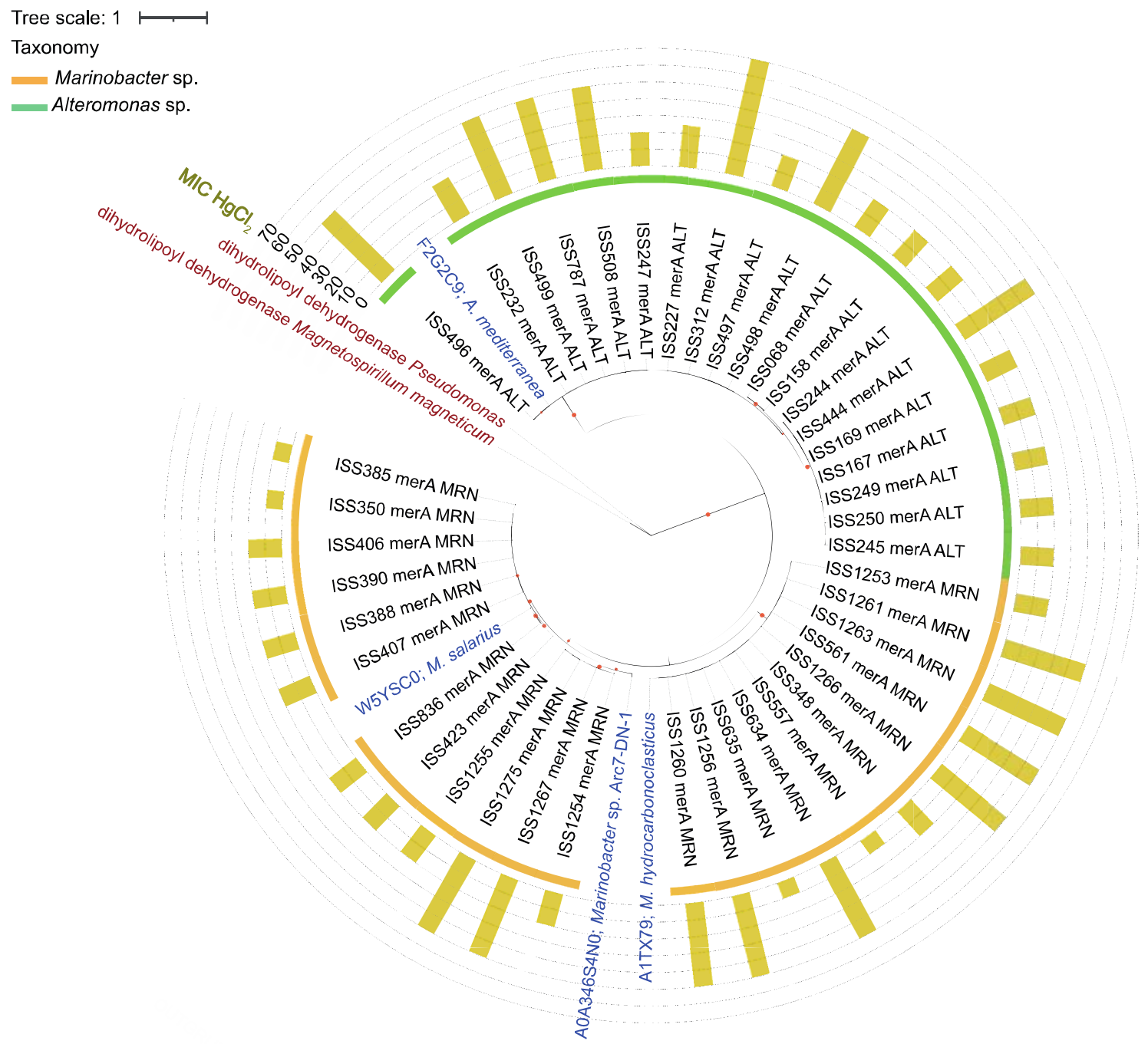

Figure 3. Phylogeny of the merA amino acid sequences from Alteromonas and Marinobacter positive strains. Including only those sequences codified in those strains submitted to Minimum Inhibitory Concentration (MIC) assays. MIC results for the tested strains against $\mathrm{HgCl}_{2}$ are indicated by bars. Sequences of dihydrolipoyl dehydrogenase act as outgroups of the tree. Color strip indicates taxonomy of the sequences: Alteromonas sp., green; Marinobacter sp., orange. Reference sequences are indicated in bold blue: A. mediterranea, 54 Alteromonas mediterranea; M. hydro., Marinobacter hydrocarbonoclasticus; M. salarius, 55 Marinobacter salarius. Bootstrap values $>75 \%$ are indicated by red circles in the tree nodes. 


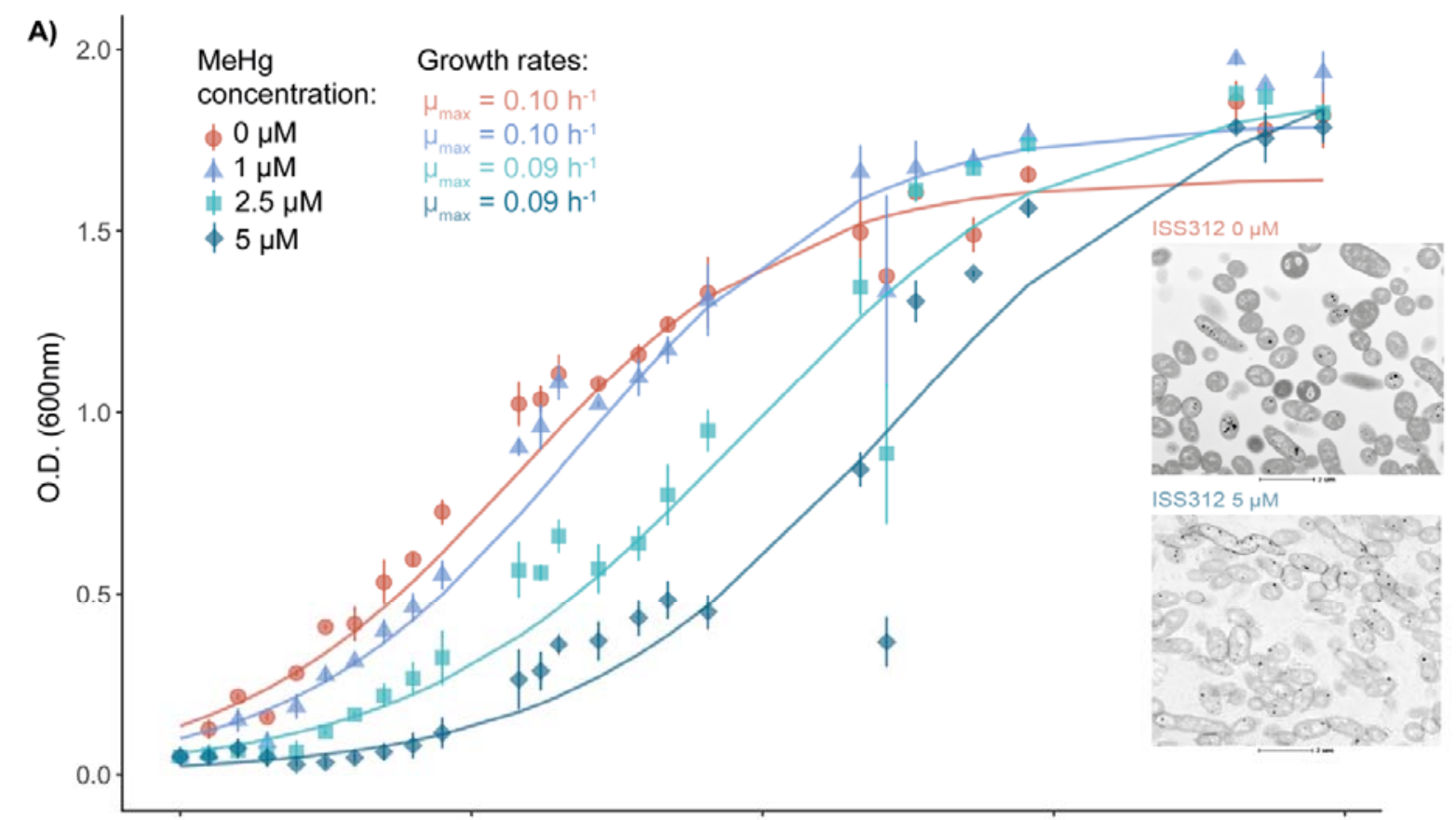

B)

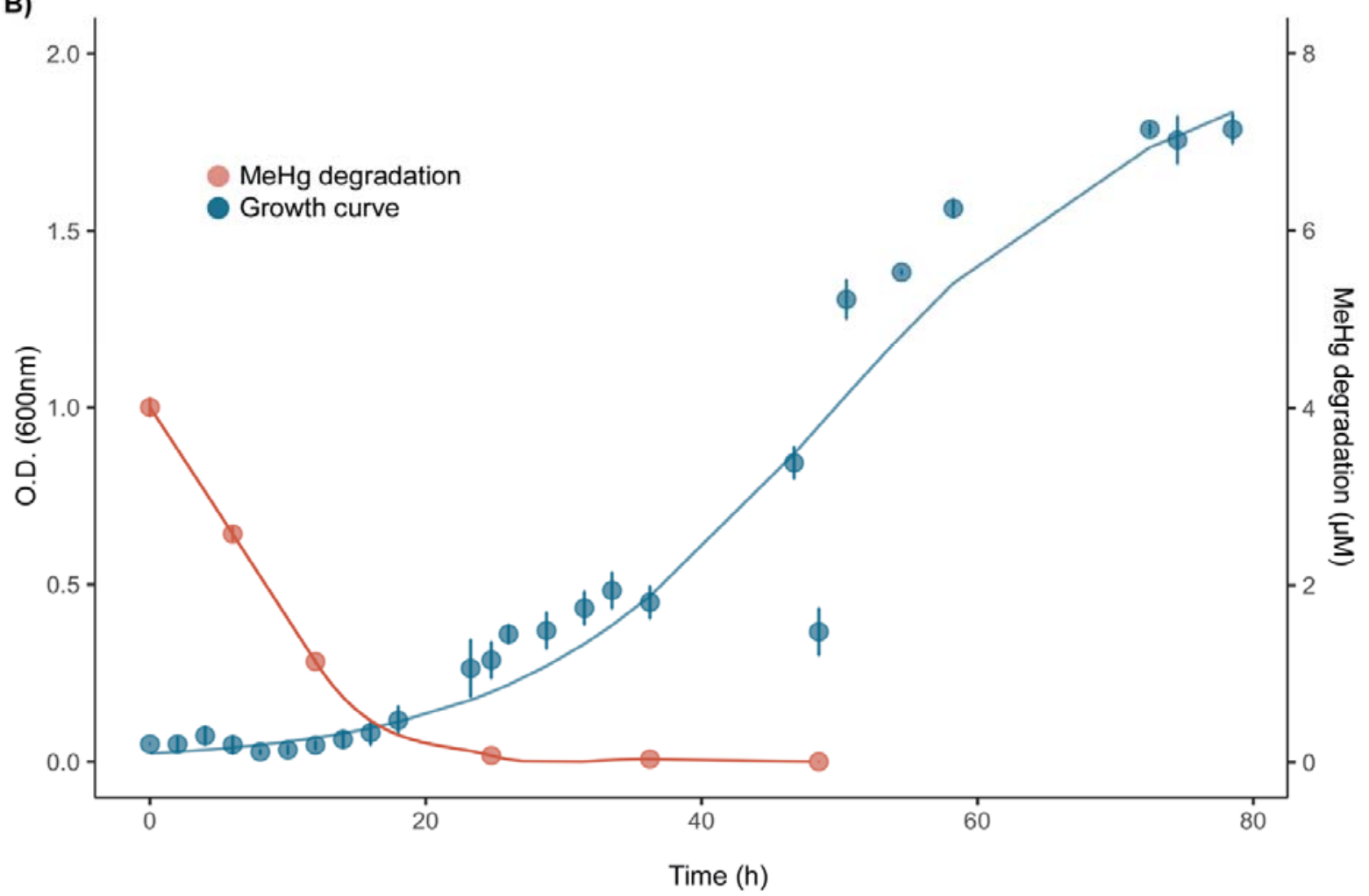

57

58 Figure 4. Growth effect of MeHg in strain ISS312. (A) Growth kinetics of Alteromonas 59 mediterranea strain ISS312 in Zobell broth containing MeHg (control $(0 \mu \mathrm{M}), 1 \mu \mathrm{M}, 2.5 \mu \mathrm{M}$ 60 and $5 \mu \mathrm{M}) . \mu_{\max }$ indicates the maximum growth rate for each MeHg concentration. TEM images 61 of the strain growing at $0 \mu \mathrm{M}$ and at $5 \mu \mathrm{M}$ are shown in the right side of the plot. (B) $\mathrm{MeHg}$ 62 removal by strain ISS312 during the growth curve experiment at $5 \mu \mathrm{M}$. Mean and standard 63 deviation from three replicates samples are shown in both graphs.

64 
65

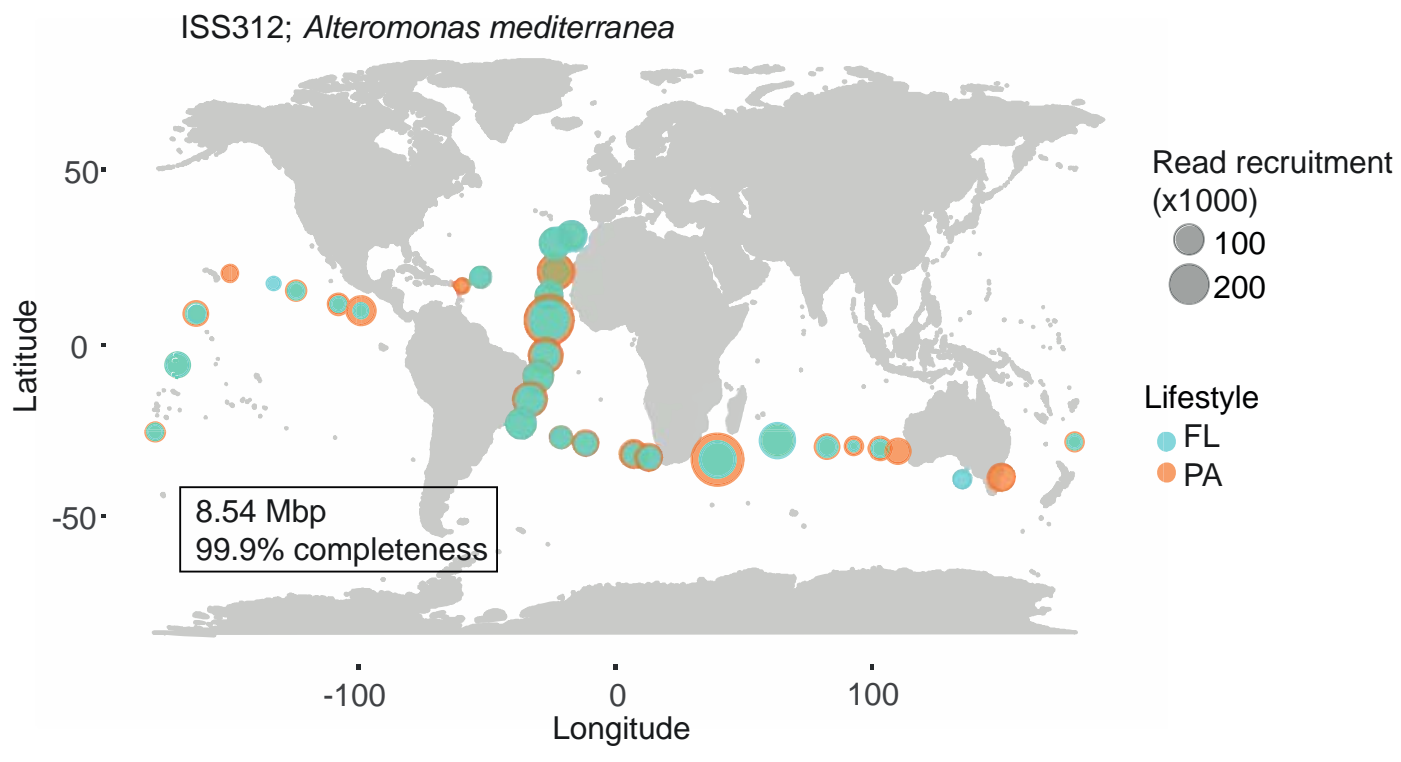

Figure 5. World map showing the distribution of Alteromonas mediterranea strain ISS312.

69 Size of the dots indicate number of reads (x1000) and color indicate if the reads were recruited

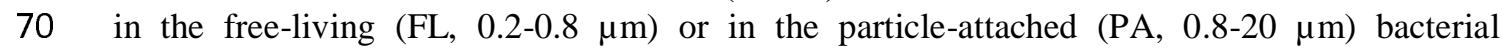
71 communities of the bathypelagic samples. 
Alteromonas mediterranea DE; 64255105

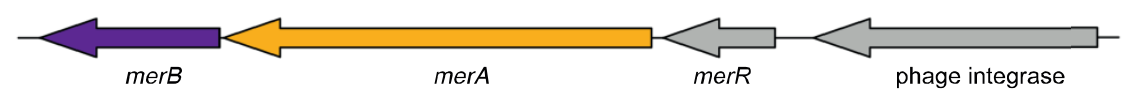

Marinobacter aquaeolei VT8; 639633037

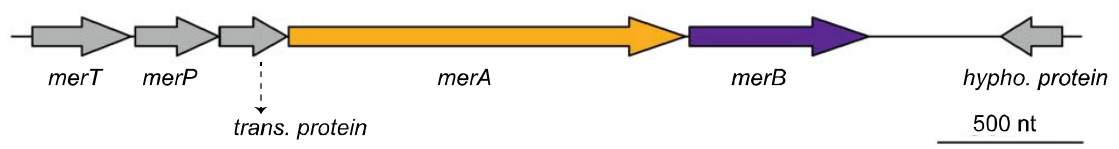

B) Marinobacter spp. Alteromonas spp.

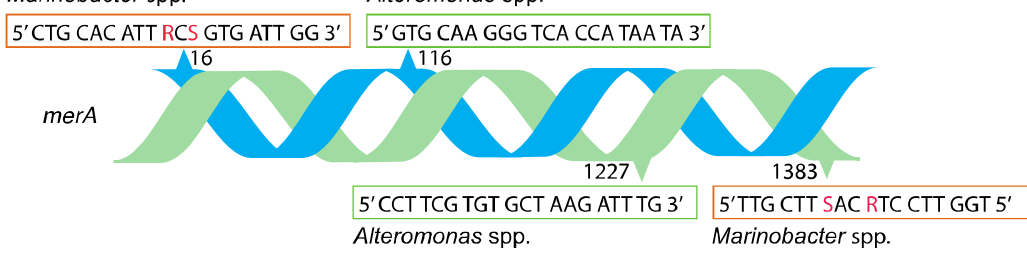

Alteromonas mediterranea Marinobacter hydrocarbonoclasticus

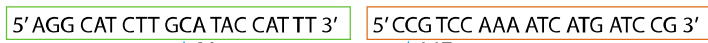

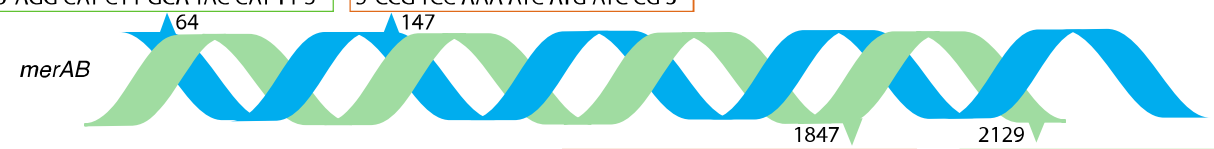

Figure 6. Synteny and primers of merA and merB genes. (A) Co-localization of merA and merB genes in Alteromonas mediterranea DE and Marinobacter aquaeolei VT8. Coordinates extracted from the JGI/IMG database. Accession number in the IMG/JGI database is indicated with the species name. Genes: merA, mercuric reductase; merB, organomercurial lyase; merR, mer operon regulator; merT, merP and trans. prot.: mercury transport proteins; hypho. prot: hypothetical protein. (B) Forward (blue chain) and reverse (green chain) primers sequences for merA and merAB genes. Numbers indicate the position where primers attached to the forward and reverse DNA strands. Some of the primers display degenerated bases (see in red): R: A or 